\title{
Chemical methods for the characterization of proteolysis in cheese during ripening
}

\author{
PLH McSweeney, PF Fox \\ Department of Food Chemistry, University College, Cork, Ireland
}

\begin{abstract}
Summary - Proteolysis is the principal and most complex biochemical event which occurs during the maturation of most cheese varieties. Proteolysis has been the subject of much study and a range of analytical techniques has been developed to assess its extent and nature. Methods for assessing proteolysis can be classified under two broad headings: non-specific and specific techniques, both of which are reviewed. Non-specific techniques include the quantitation of nitrogen soluble in various extractants or precipitants and the liberation of reactive groups. Specific techniques include those which resolve individual peptides or free amino acids, principally chromatography or electrophoresis. Techniques are often combined into a fractionation scheme for cheese nitrogen to facilitate the isolation of individual peptides. Methods for the identification of individual peptides are also reviewed. Strategies for assessing proteolysis in various cheese varieties are discussed.
\end{abstract}

proteolysis / cheese ripening / methodology

Résumé - Méthodes chimiques pour la caractérisation de la protéolyse des fromages durant l'affinage. La protéolyse, qui est le phénomène principal et le plus complexe intervenant dans la maturation de la plupart des fromages, a été le sujet de nombreuses études. Toute une gamme de techniques analytiques a été développée afin de permettre une meilleure compréhension de ce phénomène. Les méthodes de suivi de la protéolyse peuvent être classées en deux grands chapitres, traités dans cette revue : les techniques non spécifiques, et les techniques spécifiques. Les techniques non spécifiques incluent la quantification de l'azote soluble dans les divers extraits, et s'intéressent aussi à la libération des groupements réactifs. Les techniques spécifiques, principalement la chromatographie ou l'électrophorèse, sont celles permettant de séparer les peptides ou les acides aminés libres. Ces diverses techniques sont souvent combinées dans la stratégie de purification de la fraction azotée du fro-

Oral communication at the IDF Symposium 'Ripening and Quality of Cheeses', Besançon, France, February 26-28, 1996. 
mage afin de pouvoir isoler individuellememt les peptides. Les méthodes d'identification des peptides, ainsi que les différentes stratégies de suivi de protéolyse dans diverses variétés de fromages sont discutées dans cette revue.

protéolyse / affinage du fromage / méthodologie

\section{INTRODUCTION}

The biochemistry of cheese ripening is normally considered under three general headings: proteolysis, lipolysis and glycolysis. Of these processes, proteolysis is the most important for most ripened cheese varieties (Fox et al, 1995a). Proteolytic agents in cheese originate from five sources: 1) the coagulant; 2) indigenous and endogenous proteinases from the milk; 3 ) the starter; 4) the adjunct starter; and 5) non-starter lactic acid bacteria.

\section{The coagulant}

Chymosin and bovine pepsin in the case of calf rennet or recombinant chymosin or fungal aspartyl proteinases in cheeses manufactured using rennet substitutes are principally responsible for the production of large peptides (Visser, 1977; McSweeney et al, 1994a).

\section{Indigenous and endogenous proteinases from the milk}

The principal indigenous proteinase in milk is plasmin, but somatic cell proteinases and enzymes from the native microflora of the milk (particularly heat-stable proteinases from psychrotrophs) are also present (Fox et al, 1995a).

\section{The starter}

Lactococcus spp, Lactobacillus spp and Streptococcus salivarius ssp thermophilus used as starters for cheesemaking have extensive proteinase/peptidase systems (see Exterkate, 1995;
Bockelmann, 1995) which contribute to proteolysis in cheese, particularly at the level of the production of short peptides and free amino acids (Visser, 1977).

\section{The adjunct starter}

Proteinases and peptidases from the adjunct starter are particuarly important for proteolysis in certain cheese varieties. Penicillium spp and microorganisms from the smear of bacterial surface-ripened cheeses produce potent extracellular proteinases and peptidases (Gripon, 1993; Reps, 1993).

\section{Non-starter lactic acid bacteria}

The microflora of essentially all cheeses is characterized by the growth of adventitious nonstarter lactic acid bacteria, NSLAB (typically Lactobacillus spp but also Pediococcus spp and perhaps other genera). The contribution of NSLAB to cheese quality has been the subject of much recent research (see Peterson and Marshall, 1990; Martley and Crow, 1993; McSweeney et al, 1995, for references). The contribution of NSLAB enzymes to proteolysis in Cheddar cheese appears to be relatively minor and at the level of the production of short peptides and free amino acids (McSweeney et al, 1994b; Lane and Fox, 1996).

The extent and nature of proteolysis show considerable intervarietal variation caused by differences in production protocols and ripening conditions (particularly whether a secondary microflora is encouraged). Proteolysis is very limited in Pasta Filata varieties (eg, Mozzarella) due to denaturation of enzymes during high- 
temperature stretching, while in mould-ripened varieties (particularly blue mould cheeses) proteolysis is extensive due to the presence of potent fungal proteinases.

The products of proteolysis vary in size from large peptides comparable to intact caseins (eg, $\alpha_{\mathrm{s} 1}-\mathrm{CN}$ f24-199, the primary product of chymosin action on $\alpha_{\mathrm{s} 1}$-casein) to free amino acids and their degradation products. Proteolysis has important consequences for the development of cheese texture due to cleavage of the protein matrix (Creamer and Olson, 1982; Lawrence et al, 1983) and flavour through the production of the precursors of a number of volatile flavour compounds and directly by the liberation of amino acids and certain peptides (see Fox et al, 1995a).

Because of its central role in cheese ripening, techniques for the assessment of proteolysis have been reviewed (Rank et al, 1985; Fox, 1989; IDF, 1991; McSweeney and Fox, 1993; Fox et al, 1995b). These reviews suggest that techniques for the assessment of proteolysis in cheese fall into two general categories: non-specific and specific methods. Non-specific methods include determination of the nitrogen $(\mathrm{N})$ soluble or extractable in various solvents or measurement of reactive groups, while specific techniques are those which resolve individual peptides, ie, electrophoretic and chromatographic methods. Non-specific methods provide adequate information on the overall extent of proteolysis and the general contribution of the various agents to proteolysis. Such techniques are generally simple and are valuable for the routine assessment of cheese maturity. The thorough study of proteolysis necessitates the isolation and identification of peptides; therefore techniques which resolve individual peptides, such as electrophoresis and chromatography, have received considerable attention in recent years. The objective of this review is to assess methodology for the study of proteolysis, but not to simply catalogue methods used by specific authors. In the case of widely-used techniques, only a few recent representative references are supplied. If further references are required, the reader is referred to the above reviews.

\section{NON-SPECIFIC METHODS FOR ASSESSING PROTEOLYSIS}

\section{Extraction / solubility methods}

The caseins are insoluble in many solvents, but peptides produced from them may be soluble and thus the proportion of soluble nitrogen will increase with proteolysis. This is the principle of a number of widely-used methods for assessing proteolysis in cheese during ripening. Such methods are particularly useful for determining the extent of proteolysis, since peptides of varying size can be precipitated by careful choice of solvents. A number of the solvent systems described below are also used to extract peptides as the first step in their purification.

\section{Hydraulic pressure/centrifugation}

The aqueous phase of cheese ('cheese juice') can be prepared by subjecting a cheese/sand mixture to hydraulic pressure (eg, $30 \mathrm{MPa}$ ). Preparation of cheese juice by hydraulic pressure has the advantage of not altering the ionic composition of the aqueous phase of cheese and has been exploited principally in studies on calcium phosphate in cheese, the buffering capacity of cheese and in studies on the lysis of starter cells. Authors who have used this technique include Morris et al (1988), Wilkinson et al (1992), Lucey et al (1993), Wilkinson et al (1994) and Salvat-Brunaud et al (1995). Preparation of the aqueous phase of cheese by centrifugation has the same advantages. Guo and Kindstedt (1995) prepared the aqueous fraction of Mozzarella by centrifugation at $12500 \mathrm{~g}$ for $75 \mathrm{~min}$ at $25^{\circ} \mathrm{C}$.

\section{Urea}

The proteins and large polypeptides in cheese are completely soluble in 4 to $6 \mathrm{~mol} / \mathrm{L}$ urea, which is used to prepare samples for analysis by chromatography or electrophoresis (see below). 


\section{Water}

Water is perhaps the most commonly used extractant for cheese N. The level of water-soluble N (WSN) is a widely-used index of cheese ripening (see Rank et al, 1985; Fox et al, 1995b) and several procedures have been developed (see Christensen et al, 1991). Water is frequently used as the primary extractant in the isolation of amino acids and peptides.

Kuchroo and Fox (1982a) compared various extraction techniques for Cheddar cheese. All but one of the several homogenization techniques studied yielded essentially similar results; a stomacher was chosen for routine work. Homogenization temperature (in the range $5-40{ }^{\circ} \mathrm{C}$ ) had little effect on the level of extractable $\mathrm{N}$, which increased with the ratio of water to cheese; a ratio of 2:1 was recommended, and $90 \%$ of the potentially water-extractable $\mathrm{N}$ was recovered in two extractions. The procedure recommended is: grated cheese is homogenized in a stomacher at $20^{\circ} \mathrm{C}$ for 10 min with twice its weight of water; the slurry is held at $40^{\circ} \mathrm{C}$ for $1 \mathrm{~h}$, centrifuged and the supernatant filtered through glass wool and Whatman no 113 filter paper. The residue can be re-extracted to increase the yield of extract. This and similar procedures have been used by a number of workers (eg, González de Llano et al, 1991; Tieleman and Warthesen, 1991; Wilkinson et al, 1992; Bütikofer et al, 1993; Singh et al, 1995, 1996).

The water-soluble extract (WSE) of Cheddar cheese contains numerous small-and medium-sized peptides, free amino acids and their degradation products, organic acids and their salts; extraction with water efficiently separates the small peptides in cheese from proteins and large peptides. In many cheeses, the principal proteolytic agents responsible for the production of WSN are the coagulant (chymosin) and, to a lesser extent, plasmin (Visser, 1977; Fox et al, 1995a). Starter proteinases and peptidases play a relatively minor role in the hydrolysis of intact caseins and large polypeptides to water-soluble peptides, although they are active on many of the peptides released by chymosin or plasmin. Water-insoluble peptides in Cheddar cheese have been studied by McSweeney et al (1994a), who found that the principal peptides in this fraction were produced from $\alpha_{\mathrm{s1}^{1}}$-casein by chymosin or pepsin or from $\beta$-casein by plasmin and therefore that the complementary primary water-soluble peptides must be produced via the action of these enzymes. This hypothesis has been strengthened by the results of Singh et al $(1994,1995,1996)$ who isolated and identified a large number of water-soluble peptides from Cheddar cheese; with a few exceptions, these peptides corresponded directly to or were in the immediate vicinity of cleavage sites for lactococcal cell envelope-associated proteinase but generally did not include the principal cleavage sites of chymosin on $\alpha_{s 1^{-}}$or plasmin on $\beta$-casein, suggesting that chymosin and plasmin act first.

WSN as a percentage of total $\mathrm{N}$ varies with variety and increases throughout ripening (fig 1); a typical value for mature Cheddar cheese is $\sim 25 \%$. Water is a suitable extractant for internal bacterially-ripened cheese varieties, the $\mathrm{pH}$ of which changes little during ripening. However, mould and bacterial surface-ripened varieties are characterized by an increase in $\mathrm{pH}$ during ripening; and since the extractability of $\mathrm{N}$ varies with $\mathrm{pH}$, an alternative method should be adopted.

\section{Extraction with solutions containing salts}

Extraction and quantification of cheese $\mathrm{N}$ soluble at $\mathrm{pH} 4.6(\mathrm{pH} 4.6-\mathrm{SN})$ is widely used as an index of proteolysis. Since the $\mathrm{pH}$ of many internal bacterially-ripened varieties is $\sim 5.2$, there is little difference between the levels extracted by water or $\mathrm{pH} 4.6$ buffers. However, in the case of cheeses characterized by an increase in $\mathrm{pH}$ during ripening, WSN may be considerably higher than $\mathrm{pH}$ 4.6-SN. Like WSN, pH 4.6-SN is produced mainly by rennet ( $\mathrm{O}^{\prime} \mathrm{Keeffe} e \mathrm{et}$, 1976) and increases during ripening (eg, fig 1). Whey proteins and proteose peptones (from plasmin action) are also soluble at $\mathrm{pH} 4.6$, but their contribution to $\mathrm{pH} 4.6-\mathrm{SN}$ is relatively small; 


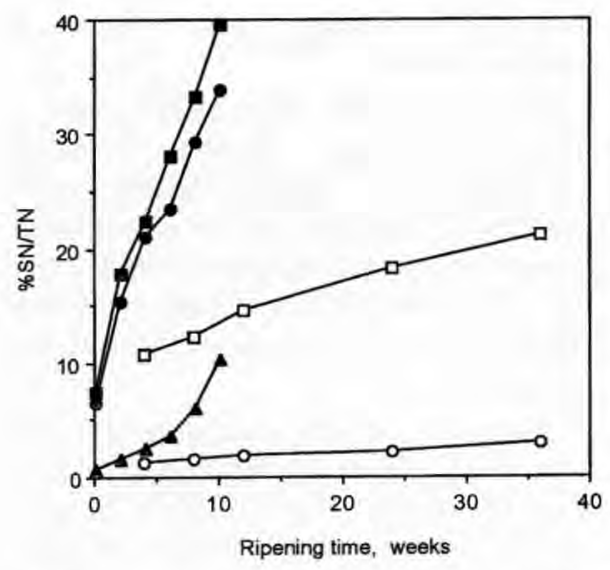

Fig 1. Formation of $\mathrm{pH} 4.6$-soluble $\mathrm{N}(\boldsymbol{\square}), 12 \%$ trichloroacetic acid-soluble $\mathrm{N}(\mathbf{O})$ and $5 \%$ phosphotungstic acid (PTA)-soluble $\mathbf{N}(\boldsymbol{\Delta})$ in an Irish artisanal blue cheese and formation of water-soluble $\mathrm{N}$ $(\square)$ and PTA-soluble $\mathrm{N}(\mathrm{O})$ in a commercial Cheddar cheese. Modified from Folkertsma et al (1996) and Zarmpoutis et al (1996).

Formation de $\mathrm{N}$-soluble à $\mathrm{pH} 4,6$ ( $\mathbf{\square}), \mathrm{N}$-soluble dans TCA $12 \%$ (- et $N$-soluble dans PTA $5 \%$ (4), dans un fromage bleu irlandais d'origine artisanale et formation de $\mathrm{N}$-soluble dans l'eau ( $\square$ ) et $\mathrm{N}$-soluble dans PTA (O), dans un fromage de cheddar commercial. Modifié d'après Folkertsma et al (1996) et Zarmpoutis et al (1996).

$\gamma$-caseins are insoluble at $\mathrm{pH} 4.6$ (see Rank et al, 1985). According to Kuchroo and Fox (1982a), this method gives slightly lower values for soluble $\mathrm{N}$ than extraction with water; and although it is more difficult to perform, it may be easier to standardize (Fox, 1989). Recent studies in which $\mathrm{pH} 4.6-\mathrm{SN}$ has been used as an index of ripening include those by Lau et al (1991), Addeo et al (1992), Bütikofer et al (1993), Picon et al (1994), Yun et al (1995) and Zarmpoutis et al (1996).

Precipitation of casein-derived peptides by $\mathrm{CaCl}_{2}$ has been used by some investigators. Solutions containing $\mathrm{CaCl}_{2}$ have been used as the primary extractant or as a method to subfractionate WSN (Lau et al, 1991; Addeo et al, 1992; Bütikofer et al, 1993). Noomen (1977a) and Venema et al (1987) homogenized cheese in $0.037 \mathrm{~mol} / \mathrm{L} \mathrm{CaCl}_{2}$, adjusted the homogenate to $\mathrm{pH} 7.5$, followed by centrifugation. Visser (1977) homogenized cheese in $4 \% \mathrm{NaCl}$ containing $0.55 \% \mathrm{Ca}\left(\right.$ as $\left.\mathrm{CaCl}_{2}\right)$. Fat was removed and the $\mathrm{pH}$ of the homogenate was adjusted to 7.5 , followed by centrifugation. Noomen (1977b) used a method based on sensitivity to coagulation by $\mathrm{pH}$ and heat to fractionate cheese N. An extract was prepared by homogenizing cheese in a $\mathrm{CaCl}_{2}(0.137 \mathrm{~mol} / \mathrm{L}) / \mathrm{NaCl}(0.684 \mathrm{~mol} / \mathrm{L})$ solution; the homogenate was adjusted to $\mathrm{pH}$ 5.1. The extract was fractionated by acidification with $0.25 \mathrm{~mol} / \mathrm{L} \mathrm{HCl}$ to a final $\mathrm{pH}$ of $\sim 1.6$ and holding at $55^{\circ} \mathrm{C}$ for $30 \mathrm{~min}$, and then overnight at room temperature before filtration.

Kuchroo and Fox (1982a) found that only $40 \%$ of the WSN was soluble in $0.1 \mathrm{~mol} / \mathrm{L}$ $\mathrm{CaCl}_{2}$. Increasing the concentration of $\mathrm{CaCl}_{2}$ above $0.05 \%$ at or above $\mathrm{pH} 7.0$ has little influence on extractability (Noomen, 1977b). The increase in $\mathrm{CaCl}_{2}$-soluble $\mathrm{N}$ correlates with the age of cheese and the extracts contain whey proteins, peptides and amino acids, while the $\mathrm{CaCl}_{2}$ insoluble fraction contains caseins and large peptides, similar to those in the water-insoluble fraction (Christensen et al, 1991).

$\mathrm{NaCl}$ has also been used to fractionate cheese N (eg, Chakravorty et al, 1966; Gupta et al, 1974), but Reville and Fox (1978) claimed that $>90 \%$ of Cheddar cheese $\mathrm{N}$ was soluble in $5 \% \mathrm{NaCl}$, which was thus not sufficiently discriminating, except perhaps for very young cheeses. $\mathrm{NaCl}(5 \%)$-soluble $\mathrm{N}$ and unfractionated cheese are indistinguishable electrophoretically, indicating that the parent caseins, as well as peptides, are extracted (Rank et al, 1985; Bican and Spahni, 1991). Inclusion of $\mathrm{CaCl}_{2}$ in the $\mathrm{NaCl}$ solution should reduce the percentage $\mathrm{N}$ extracted and thus increase the selectivity of the method (see Fox, 1989).

\section{Extraction/fractionation with organic solvents}

Harwalkar and Elliott (1971) developed an extraction technique with chloroform/methanol 
$(2: 1, v / v)$. Freeze-dried cheese was extracted using this solvent, the extract filtered and water added. The chloroform layer contained lipids and was discarded. Removal of methanol from the aqueous methanol layer by evaporation resulted in the formation of a precipitate; the supernatant was very bitter and astringent. This method has also been used by a number of authors (eg, Lemieux et al, 1989, 1990; Puchades et al, 1989a, b, 1990; Tieleman and Warthesen, 1991) using different fractions of cheese as the starting material.

Chloroform/methanol extracts more $\mathrm{N}$ than water, which is understandable considering the relatively hydrophobic nature of many caseinderived peptides, but chromatograms of both extracts on Sephadex G-25 were similar (Rank et al, 1985). However, Tieleman and Warthesen (1991) found that extracts prepared by the method of Harwalkar and Elliott (1971) were significantly less heterogeneous, as indicated by HPLC, than extracts prepared by the methods of McGugan et al (1979) or Kuchroo and Fox (1982a).

McGugan et al (1979) developed a fractionation scheme using methylene chloride; methanol:water which has also been used by Smith and Nakai (1990).

Fractionation of proteins and peptides by ethanol is a classical technique, and has been used extensively to fractionate peptides in cheese (Christensen et al, 1991; McSweeney and Fox, 1993; Fox et al, 1995b). Ethanol concentrations used have varied from 30 to $80 \%$ (Fox et al, 1995b); 70\% has been used widely (eg, Abdel Baky et al, 1987). Trichloroacetic acid, TCA (12\%, see below) and $70 \%$ ethanol yield approximately equal extraction levels (Reville and Fox, 1978) and soluble fractions contain similar peptides (Kuchroo and Fox, 1982b), although differences are apparent in the peptides in the insoluble fractions.

An ultrafiltration (UF) retentate $(10 \mathrm{kDa})$ of a WSE of Cheddar was fractionated by Breen et al (1995) using increasing concentrations of ethanol (30-80\%); fractionation of the UF retentate containing $30 \%$ ethanol by stepwise adjust- ment of $\mathrm{pH}$ in the range 5.5-6.5 was found to be quite effective.

Precipitation with ethanol may be used to fractionate cheese or to sub-fractionate WSEs, and should be preferred to the largely equivalent $12 \%$ TCA owing to the ease of removal of ethanol by evaporation (Christensen et al, 1991). Fractionation of WSEs of Cheddar using 70\% ethanol is used routinely in the authors' laboratory.

Poznanski et al (1966) fractionated 2 or $12 \%$ TCA-soluble extracts with $75 \%$ acetone acidified to $\mathrm{pH} 4.6$, while Aston and Creamer (1986) used methanol to fractionate a WSE of Cheddar. Butan-1-ol has been used to extract bitter peptides from casein hydrolysates (McSweeney and Fox, 1993) but does not appear to have been applied to the fractionation of cheese. This extractant may have potential for the isolation of bitter and/or hydrophobic peptides.

\section{Fractionation using trichloroacetic or trifluoroacetic acids}

Trichloroacetic acid $\left(\mathrm{CCl}_{3} \mathrm{COOH}\right.$; TCA) is a classical protein precipitant which has been used widely for this purpose. Concentrations ranging from 2 or $2.5 \%$ (eg, Reville and Fox, 1978; O'Sullivan and Fox, 1990) to $12 \%$ (eg, Bican and Spahni, 1991; Folkertsma and Fox, 1992; Addeo et al, 1992; Bütikofer et al, 1993; Katsiari and Voutsinas, 1994; Picon et al, 1994; Yun et al, 1995) have been used, depending on the degree of fractionation required (larger peptides being soluble at the lower TCA concentrations). There is no 'precipitation threshold' relating peptide size to solubility in TCA, but all peptides studied by Yvon et al (1989) containing less than seven amino acid residues were soluble in $12 \%$ TCA; peptide solubility is related to hydrophobicity. The majority of $12 \%$ TCAsoluble peptides isolated and identified from Parmigiano-Reggiano cheese by Addeo et al (1994) were phosphopeptides. Typically, in a mature Cheddar about $15 \%$ of the total N (Reville and Fox, 1978) and $-90 \%$ of the WSN (Kuchroo and Fox, 1982b) is soluble in 2.5\% 
TCA; while $50-60 \%$ of a UF retentate $(10 \mathrm{kDa}$ membranes) and $100 \%$ of the UF permeate (O'Sullivan and Fox, 1990) is soluble in $2 \%$ TCA.

Rennet is responsible for the production of some of the $12 \%$ TCA-soluble N, but starter proteinases and peptidases make a substantial contribution (Reiter et al, 1969; O'Keeffe et al, 1976) to the formation of $12 \%$ TCA-soluble N. Venema et al (1987) reported that the level of $12 \%$ TCA-soluble $\mathrm{N}$ is a better index of maturity than WSN. The development of $12 \%$ TCA-soluble $\mathrm{N}$ in an Irish artisanal blue cheese is shown in figure 1.

A major disadvantage of TCA for peptide fractionation is the need to remove it prior to further analysis of the fractions. Since small peptides and free amino acids will be lost on dialysis, other methods for removal of TCA, eg, repeated ether extraction or some form of chromatography, are required and are laborious procedures (Fox, 1989). The use of $70 \%$ ethanol, which gives similar precipitation levels, is preferable because ethanol can be readily removed by evaporation (Fox, 1989).

Trifluoroacetic acid $\left(\mathrm{CF}_{3} \mathrm{COOH}\right.$; TFA $)$ as a precipitant or extractant for cheese peptides may be a useful alternative to TCA, and it has the major advantage of being easily removed by evaporation. Perhaps surprisingly, there are few references to its use in the fractionation of cheese. Bican and Spahni $(1991,1993)$ used a buffer containing TFA as an extractant for Appenzeller cheese. The procedure involved homogenization at $4{ }^{\circ} \mathrm{C}$ in TFA $(1 \%, v / v) / f o r m i c$ acid $(5 \% \mathrm{v} / \mathrm{v}) / 1 \%(\mathrm{v} / \mathrm{v}) \mathrm{NaCl} / 1 \mathrm{~mol} / \mathrm{L} \mathrm{HCl}$ at $4{ }^{\circ} \mathrm{C}$, followed by centrifugation and application to a Sep-Pak $\mathrm{C}_{18}$ cartridge. The use of TFA as an ion-pair reagent in HPLC buffers is widespread (see below).

\section{Phosphotungstic acid and similar techniques}

It is often desirable to precipitate all peptides from a cheese extract in order to quantify free amino acids in the cheese since nitrogen soluble in such precipitants is a crude measure of free amino acids. Samples for amino acid analysis (see below) must also be rendered free of peptides.

Phosphotungstic acid (tungstophosphoric acid; $12 \mathrm{WO}_{3} \cdot \mathrm{H}_{3} \mathrm{PO}_{4} \cdot \mathrm{HH}_{2} \mathrm{O}$; PTA)- $\mathrm{H}_{2} \mathrm{SO}_{4}$ is a very discriminating protein precipitant; only free amino acids (apart from lysine and arginine), and peptides less than about $600 \mathrm{Da}$ are soluble in 5\% PTA (Jarrett et al, 1982). PTA (1. 2.5, 5, 6 or $6.5 \%$ )-soluble $\mathrm{N}$ has been used widely as an index of free amino acids in cheese (eg, Wilkinson et al, 1992; Bütikofer et al, 1993; Picon et al, 1994; Guinee et al, 1995). The most widelyused PTA concentration is 5\%. The short PTAsoluble peptides in some cheese varieties have been studied (Jarrett et al, 1982; Bican and Spahni, 1991; González de Llano et al, 1991). The development of 5\% PTA-soluble N in Cheddar and an Irish artisanal blue cheese is shown in figure 1.

5-Sulphosalicylic acid (2-hydroxy-5-sulphobenzoic acid; SSA), a discriminating protein precipitant, has been used at $3 \%$ to prepare extracts of cheese for amino acid analysis (Reiter et al, 1969; Ramos et al, 1987), or as an index of amino acid N (Cliffe and Law, 1991). However, Kuchroo and Fox (1982a) found that 2.5\% SSA precipitated only $10 \%$ of the WSN. The watersoluble peptides in the fractions obtained with SSA do not appear to have been characterized.

Picric acid (2, 4, 6-trinitrophenol) is also a very discriminating protein precipitant (Fox, 1989). Reville and Fox (1978) found that of the methods examined $0.85 \%$ picric acid-soluble extracts of cheese contained the lowest levels of N. It was considered to be the most suitable extractant for amino acids, but small peptides are also soluble in picric acid (Salji and Kroger, 1981). Picric acid interferes with the determination of $\mathrm{N}$ by Kjeldahl or spectrophotometric methods (Reville and Fox, 1978; Fox, 1989).

Free amino acids were extracted from Cheddar by Hickey et al (1983) using $\mathrm{Ba}(\mathrm{OH})_{2} /$ $\mathrm{ZnSO}_{4}$. Cheese $(10 \mathrm{~g})$ was macerated in $33 \mathrm{~mL}$ $0.15 \mathrm{~mol} / \mathrm{L} \mathrm{Ba}(\mathrm{OH})_{2}$ and $33 \mathrm{~mL} 0.14 \mathrm{~mol} / \mathrm{L}$ $\mathrm{ZnSO}_{4}$, filtered and residual fat removed by extraction with cholorform/ethanol (1:1). The aqueous phase was filtered and the filtrate freeze- 
dried and dissolved in a sodium citrate buffer prior to amino acid analysis. No data were given on extraction levels or whether peptides were soluble. This reagent has not been used extensively to fractionate cheese $\mathrm{N}$ nor to prepare samples for amino acid analysis.

\section{Miscellaneous techniques for fractionating peptides}

Phosphopeptides (or other peptides with a high negative charge) can be precipitated from a water extract of cheese by addition of $\mathrm{BaCl}_{2}$ to a final concentration of 10 to $50 \mathrm{mmol} / \mathrm{L}$ and adjusting the $\mathrm{pH}$ to $6.7-7.0 . \mathrm{Ba}^{2+}$ complex with serine phosphate residues of phosphopeptides (and potentially other negatively charged groups) which can then be precipitated by adding ethanol $(20 \% \mathrm{v} / \mathrm{v})$ and recovered by centrifugation $\left(3000 \mathrm{~g}, 30 \mathrm{~min}, 4^{\circ} \mathrm{C}\right.$ ). The pellet can be redissolved in water and adjusted to $\mathrm{pH}<2.0$ using $\mathrm{H}_{2} \mathrm{SO}_{4}$ to precipitate $\mathrm{BaSO}_{4}$. This method, based on that of Peterson et al (1957), has been used in the authors' laboratory to prepare phosphopeptides from Cheddar. Kuchroo and Fox (1982b) fractionated a WSE of Cheddar with $0.1 \mathrm{~mol} / \mathrm{L}$ ethylenediamine tetraacetic acid (EDTA); approximately $30 \%$ of the WSN was precipitated. However, EDTA does not appear to have been used by other authors for this purpose.

Fernández and Fox (1997) fractionated peptides in the water-soluble and -insoluble fractions of Cheddar cheese using chitosan (a polymer of $\mathrm{N}$-glucosamine). Chitosan is polycationic at acid $\mathrm{pH}$ and thus can complex with negatively-charged molecules, leading to their flocculation. Chitosan $(0.02 \%)$ was unsuitable for the fractionation of water-insoluble peptides but fractionated water-soluble peptides quite effectively at $\mathrm{pH}$ 4.0. Chitosan-peptide complexes were dissociated at $\mathrm{pH} 7.0$.

\section{Fractionation techniques based on molecular mass}

Techniques for the fractionation of peptides based on their molecular mass, ie, dialysis, ultra- filtration and size-exculsion chromatography have been used as an alternative to techniques based on peptide solubility in various reagents.

Kuchroo and Fox (1982b) found that exhaustive dialysis ( $96 \mathrm{~h}$, four changes) was a simple and effective method for partitioning water-soluble peptides, and that it was suitable for relatively large samples. About $50 \%$ of the WSN in a mature Cheddar was dialysable; the diffusate was completely soluble and the retentate $50 \%$ soluble in $70 \%$ ethanol. This technique was included by Kuchroo and Fox (1983b) in their fractionation scheme. Sciancalepore and Alviti (1987) dialysed unfractionated, grated cheese $(1 \mathrm{~g})$, dispersed in $\mathrm{H}_{2} \mathrm{O}(1 \mathrm{~mL})$, against $\mathrm{H}_{2} \mathrm{O}$ $(10 \mathrm{~mL})$ at $30^{\circ} \mathrm{C}$ for $30 \mathrm{~min}$. The $\mathrm{A}_{280}$ of the dialysate correlated well with age and with $12 \%$ TCA-soluble and $\mathrm{pH} 4$.6-soluble N. This method was also used by González de Llano et al (1993) to study proteolysis in blue cheese.

While dialysis is a simple and useful technique for peptide fractionation, it has been superseded by ultrafiltration (UF) which is faster, capable of handling larger samples, uses membranes of known molecular mass cut-off and reduces the problem of recovering peptides from a large volume of diffusate. Many authors have used diafiltration to improve resolution. Membranes with nominal molecular weight cut-offs ranging from 0.5 to $10 \mathrm{kDa}$ (most commonly) have been used. Most authors have used UF to fractionate the larger peptides in cheese, although Visser et al (1983a, b) isolated very low molecular weight peptides from a bitter extract of cheese by UF on $0.5 \mathrm{kDa}$ membranes, and Aston and Creamer (1986) used ultrafiltration with $1 \mathrm{kDa}$ cut-off membranes to fractionate WSN. All peptides in a $10 \mathrm{kDa}$ UF permeate are soluble in $2 \%$ TCA, but some peptides in the retentate are insoluble (O'Sullivan and Fox, 1990); the permeate contains no peptides detectable by polyacrylamide gel electrophoresis (PAGE) when stained using Coomassie blue G250, and $40-50 \%$ of the WSN is permeable. UF was used by Singh et al $(1994,1995)$ as the principal fractionation technique for water-soluble peptides. 
Rejection of hydrophobic peptides by UF membranes and aggregation of small peptides are potential disadvantages of this method. However, UF allows fractionation of large samples and does not require solvents, both of which facilitate taste panel work (Fox, 1989). Despite some studies, the potential of UF membranes with low molecular weight cut-offs $(<1 \mathrm{kDa})$ to fractionate the smaller peptides from cheese has not been extensively investigated.

The use of size-exclusion chromatography to fractionate cheese peptides is discussed below.

\section{Comparison of techniques to quantify nitrogen in fractions}

The majority of studies described above have quantified nitrogen in various fractions by the macro-Kjeldahl method (Wallace and Fox, 1994). Although this method is highly repeatable, it is a slow and potentially dangerous technique. Alternative methods have also been used for this purpose, most notably by absorbance of ultraviolet light at $280 \mathrm{~nm}$ (Vakaleris and Price, 1959) or the Folin-Ciocalteau reagent. The latter method was used by Citti et al (1963) to monitor TCA-soluble peptides. The Lowry method (a combination of the Folin-Ciocalteau and biuret reagents), which is widely used in biochemistry and is simple and rapid, has been used to quantify peptides in various cheese fractions (eg, Kaminogawa et al, 1986). In the hands of a competent analyst, the Lowry method is suitable for the routine analysis of protein/peptides in cheese fractions (Wallace and Fox, 1994). According to González de Llano et al (1993), the Kjeldahl and Lowry methods gave similar results for protein/nitrogen in water-soluble extracts from blue cheeses. Protein can also be estimated by the Bradford method (which is based on a colour change in Coomassie blue on binding to protein) or by using erythrosin, but preliminary results from this laboratory suggest that these methods are unsuitable for analysis of cheese fractions.

\section{Methods based on the liberation of reactive compounds or groups}

Most of the techniques described above for the preparation of various fractions and the quantification of $\mathrm{N}$ which is soluble therein are quite time-consuming, and it is desirable to develop more rapid methods to estimate proteolysis. Such techniques are based on the liberation of specific compounds or reactive groups which are easily measured. A wide range of such techniques is available, and includes the estimation of Tyr and Trp in cheese fractions by absorbance at $280 \mathrm{~nm}$ or by the Folin-Ciocalteau reagent, protein-dye binding, reaction of liberated amino groups with various reagents or the quantification of ammonia or glutamic acid. Because of their relative simplicity, there is a growing demand for such rapid methods for assessing cheese maturity (Ardö and Meisel, 1991).

\section{Formation of ammonia}

Ammonia, formed in cheese on the deamination of free amino acids, is an important product of proteolysis in certain cheese varieties (eg, Camembert or smear-ripened varieties; Fox et al, 1995a) where it contributes to characteristic flavour and texture (by neutralization of the cheese). Several authors (eg, Furtado and Chandan, 1985; Alonso et al, 1987; Zarmpoutis et al, 1996) have indirectly monitored ammonia production by measuring the increase in the $\mathrm{pH}$ of cheeses. However, it is perhaps surprising that the development of ammonia per se has not been used more widely as an index of proteolysis. Ammonia levels in a non-protein fraction of Ulloa cheese were measured by Ordonez and Burgos (1977) using the reaction of ammonium salts with the Nessler reagent (alkaline solution of $\mathrm{K}_{2} \mathrm{HgI}_{4}$ ) with the formation of a red-brown colloidal precipitate $\left(\mathrm{NH}_{2} \mathrm{Hg}_{2} \mathrm{I}_{3}\right)$ which was measured spectrophotometrically; the concentration of ammonia was $\sim 4 \mathrm{mg} \mathrm{g}^{-1}$ cheese dry matter and increased slightly during ripening. Fernandez-Salguero et al (1989) quantified ammonia in a number of blue cheese varieties by isothermal distillation from a sample dispersed in a 


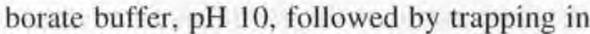
boric acid and back titration. An enzymatic assay for ammonia is available (Anonymous, 1989) which quantifies $\mathrm{NH}_{4}^{+}$by the glutamate dehydrogenase-catalyzed conversion of 2-oxoglutarate to L-glutamic acid, with the concomitant stoichiometric oxidation of NADH to $\mathrm{NAD}^{+}$ which is determined spectrophotometrically. However, this technique does not appear to have been used in cheese analysis.

\section{Formation of soluble tyrosine and tryptophan}

Measurement of the 'soluble' tyrosine and tryptophan in cheese is a well-established method for assessing proteolysis. These amino acids can be quantified by the use of Folin-Ciocalteau reagent (acidic solution of $\mathrm{Na}$ tungstate and $\mathrm{Na}$ molybdate) or by measurement of absorbance at $280 \mathrm{~nm}$. It is necessary to fractionate the cheese (eg, preparation of a water- or TCA-soluble extract) before using either of these techniques. Hull (1947) used the Folin-Ciocalteau reagent to assess proteolysis in milk. This reagent was also used by Singh and Ganguli (1972) to quantify peptides in the TCA-soluble fraction of cheese, but it appears to be less sensitive than 2, 4, 6-trinitrobenzenesulphonic acid, TNBS (Samples et al, 1984). As described above, Vakaleris and Price (1959) measured the $\mathrm{A}_{280}$ of a sodium citrate- $\mathrm{HCl}$ extract $(\mathrm{pH} 4.6)$ of cheese as an index of proteolysis.

\section{Dye-binding}

At $\mathrm{pH}$ values below their isoionic point, proteins have a net positive charge and can interact with anionic dyes (eg, amido-black, acid orange 12 or orange $G$ ) leading to the formation of an insoluble protein-dye complex. This complex can be removed by centrifugation or filtration and the excess dye in the supernatant or filtrate measured spectrophotometrically. The amount of dye bound by the protein is proportional to the concentration of protein (and thus the excess dye is inversely proportional to the protein concentration). However, low molecular weight proteins and peptides react only slowly, leading to poor separation and turbid filtrates or centrifugal supernatants.

A decrease in the dye-binding capacity of a dispersion of Cheddar cheese with age was demonstrated by Ashworth (1966). Kroger and Weaver (1979) reported that a dye-binding method could be used as an index of proteolysis in cheese, but Kuchroo et al (1983) concluded that the dye-binding method of McGann et al (1972), using amido black, is not suitable for this purpose.

The Bradford method for protein determination (Bradford, 1976) is based on the colour change in Coomassie blue $\mathrm{G} 250$ when it reacts with proteins, However, Wallace and Fox (1994) found that this technique was not suitable for quantifying water-soluble peptides.

\section{Acid/base titration}

The formol titration technique is a simple method for estimating amino groups in milk and may be used to measure the extent and rate of proteolysis. The method involves titration of a sample with $\mathrm{NaOH}$ to the phenolphthalein end-point, followed by the addition of formaldehyde which converts free amino groups to less basic secondary and tertiary amines which dissociate at a lower $\mathrm{pH}$; therefore the solution becomes more acidic, and it is necessary to re-titrate to the phenolphthalein end-point (Davis, 1965). This procedure has been used to estimate proteolysis in cheese (eg, Vakaleris et al, 1960; El Soda et al, 1981) but it is now considered obsolete owing to variations in the buffering capacity of cheese (Ardö and Meisel, 1991). Sciancalepore and Longone (1988) compared a dialysis method (Sciancalepore and Alviti, 1987) with formol titration and the method of Inikhov (1951). The latter method involved homogenization of finely ground cheese in water, followed by filtration. Samples of the filtrate were diluted and titrated with $\mathrm{NaOH}$ to thymolphthalein and phenolphthalein end points, the index of proteolysis being the difference in the titration values.

The buffering capacity of cheese increases during ripening owing to the formation of 
ammonia, amino, imino and carboxyl groups. This principle was used by Ollikainen (1990) to assess proteolysis in a Swiss-type cheese; it was claimed that the method is rapid and convenient and as accurate as colorimetric methods. Changes in the buffering capacity of Emmental around $\mathrm{pH} 9$ have been attributed to proteolysis (Lucey et al, 1993).

\section{Free amino groups-colorimetric and fluorimetric methods}

The cleavage of a pepitde bond results in the liberation of a new amino group which can react with several chromogenic or fluorogenic reagents. A number of techniques have been developed to assay proteolysis in cheese based on this principle.

2,4,6-Trinitrobenzenesulphonic acid (TNBS) is one such reagent which reacts stoichiometrically with primary amines, producing a chro- mophore which remains attached to the amino acid, peptide or protein and absorbs maximally at $420 \mathrm{~nm}$ (fig 2a). The reaction is performed at an alkaline $\mathrm{pH}$ and stopped by lowering the $\mathrm{pH}$. TNBS also reacts slowly with $\mathrm{OH}^{-}$, a reaction which is catalyzed by light. Since ammoniacal nitrogen produces only $20 \%$ of the absorbance of amino groups when reacted in equimolar concentrations with TNBS (Clegg et al, 1982), this reagent may underestimate proteolysis in cheeses which have undergone significant deamination. Clegg et al (1982) concluded that although TNBS is not as sensitive as ninhydrin for assaying proteolysis in cheese, it is preferable owing to the simple analytical procedure; they proposed a correction factor for ammoniacal nitrogen. A disadvantage of the TNBS method is that the dry powder is explosive, and prolonged storage leads to high blank values (Ardö and Meisel, 1991).

(c)

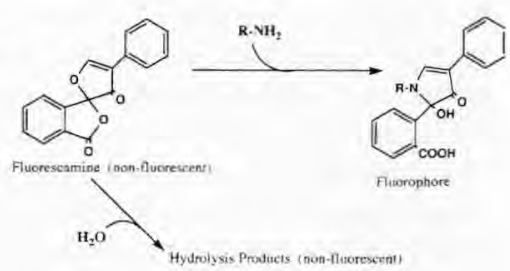

(d)

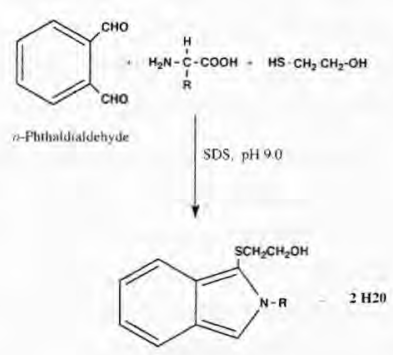

(b)
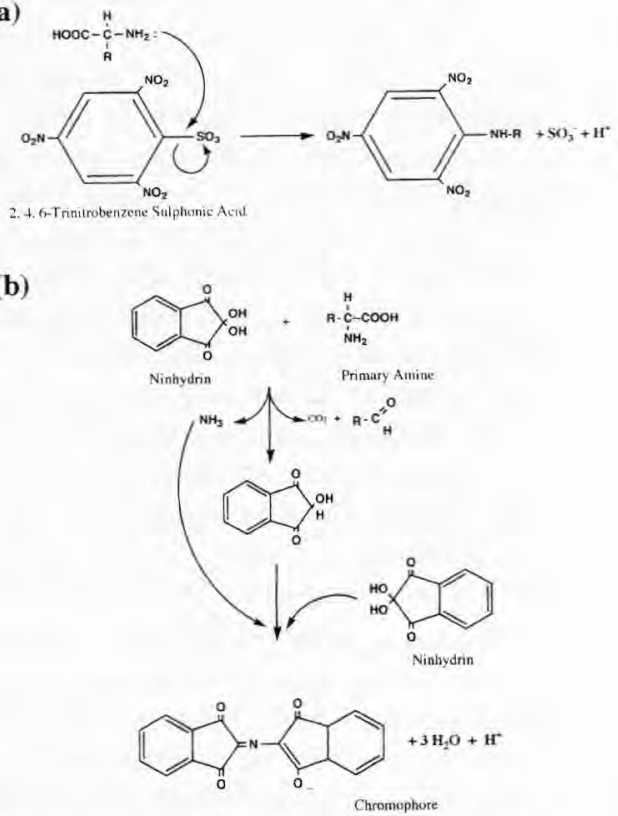

Fig 2. Reaction of (a) 2, 4, 6-trinitrobenzenesulphonic acid, (b) ninhydrin, (c) fluorescamine and (d) $o$-phthaldialdehyde with the $\alpha$-amino group of an amino acid.

Réaction de (a) l'acide 2,4,6-trinitrobenzenesulphonique, (b) de la ninhydrine, (c) de la fluorescamine et (d) de l'o-phthaldialdéhyde avec le groupe $\alpha$-aminé d'un acide aminé. 
Habeeb (1966) and Adler-Nissen (1979) measured the absorbance of the TNBS-amino group complex at $340 \mathrm{~nm}$, whereas in the procedure of Fields (1971) the absorbance of a sulphite-TNBS-amino group complex was measured at $420 \mathrm{~nm}$, thus avoiding the maximum of absorbance of TNBS itself at 335-340 nm. Barlow et al (1986) reported that the latter is preferable to the method of Habeeb (1966) in which an unstable coloured complex is formed and the procedure is liable to operator error. Alder-Nissen (1979) developed a procedure to assess the degree of hydrolysis of food proteins using TNBS; a linear relationship was found between the concentration of $\alpha$-amino groups and $\mathrm{A}_{420}$ but the relationship varied between proteins owing to variations in the concentration of lysine.

The method of Hull (1947) was compared with the TNBS method by Samples et al (1984), who found that the latter was a better index of proteolysis in cheese. Jarrett et al (1982) used the TNBS assay to quantify free amino acids in 5\% PTA-soluble fractions of cheese. The TNBS method was found to be reproducible for monitoring proteolysis in cheese (Kuchroo et al, 1983) and while unfractionated cheese could be assayed, it is more sensitive if applied to $\mathrm{pH} 4$.6or $12 \%$ TCA-soluble extracts owing to a lower background colour caused by reaction of TNBS with $\varepsilon$-amino groups. A strong correlation was found by Madkor et al (1987) between WSN and the $\mathrm{A}_{420}$ of the TNBS complex for watersoluble extracts of Stilton cheese.

Barlow et al (1986) claimed that analysis of a water-soluble extract prepared according to Kuchroo and Fox (1982a) by the TNBS method of Fields (1971) would provide a simple routine method for quantifying soluble $\mathrm{N}$ in cheese. Whole cheese, dispersed in $0.1 \mathrm{~mol} / \mathrm{L} \mathrm{Na}_{2} \mathrm{~B}_{4} \mathrm{O}_{7}$, $0.1 \mathrm{~mol} / \mathrm{L} \mathrm{NaOH}, \mathrm{pH} 9.5$, was analyzed by Polychroniadou (1988), who found a good correlation between the results of the TNBS method and WSN determined by the Kjeldahl procedure; fractionation of the cheese prior to analysis was considered to be unnecessary. The TNBS method was also used by Lemieux et al (1990), who compared a flow-injection technique for the TNBS and $o$-phthaldialdehyde (see below) assays with classical methods. Bouton and Grappin (1994) found a good relationship between PTA-soluble $\mathrm{N}$ values (by Kjeldahl) and the TNBS method.

Ninhydrin is also widely used to monitor the liberation of free amino groups in cheese during ripening. The principle of the ninhydrin reaction is the spectrophotometric estimation of a chromophore formed when ninhydrin reacts with free amino groups (fig 2b). The purple chromophore, named Ruhemann's purple after its discoverer, does not remain attached to the protein or peptide and therefore is not precipitated during procedures necessary to clarify the sample prior to spectrophotometric analysis at $570 \mathrm{~nm}$ (Ardö and Meisel, 1991), which is a major advantage of the technique (Pearce et al, 1988). The $\lambda_{\max }$ of the chromophore is shifted to a shorter wavelength $(-507 \mathrm{~nm})$ when the water content of the reaction mixture is reduced (Doi et al, 1981). Ninhydrin reacts with ammonia almost as readily as with amino groups and therefore levels of proteolysis found by ninhydrin assays are consistently higher than those found by the TNBS procedure, the discrepancy being due to ammonia (Clegg et al, 1982). Ninhydrin is more sensitive than TNBS, but the latter was preferred by Clegg et al (1982) because the analytical procedure is simpler. Ninhydrin is widely used to quantify amino groups in chromatographic eluates, particularly in amino acid analysis by ion-exchange chromatography followed by post-column derivatization (see below). Cliffe et al (1989) used ninhydrin to monitor fractions obtained by reversed-phase chromatography.

Pearce et al (1988) developed a Li-ninhydrin assay for proteolysis in cheese based on that of Friedman et al (1984): an aliquot of cheese dispersed in a citrate buffer was mixed with aqueous solutions of dimethyl sulphoxide, ninhydrin and lithium acetate at $\mathrm{pH} 5.2$, heated, diluted and $\mathrm{A}_{570}$ determined. Total free amino acids determined by this method correlated well with conventional amino acid analyses. 
Doi et al (1981) described a number of ninhydrin-based assays for peptidase activity; two were modifications of the methods of Moore and Stein $(1948,1954 b)$ and two were based on the Cd-ninhydrin assay of Tsarichenko (1966). The Cd-ninhydrin reagent was found to be more selective for the amino group of free amino acids than for the amino groups of peptides or proteins and was the most sensitive of several ninhydrin reagents, including $\mathrm{Sn}$-ninhydrin. Folkertsma and Fox (1992) applied the Cd-ninhydrin assay of Doi et al (1981) to the assessment of proteolysis in cheese; the reagent was found to be about five times as sensitive as TNBS for the measurement of amino acid nitrogen and could be performed on citrate-, water- or PTA-soluble fractions but not on TCA-soluble fractions, as the latter appeared to interfere with colour development. The release of total free amino acids in cheese, as determined by the Cd-nin-

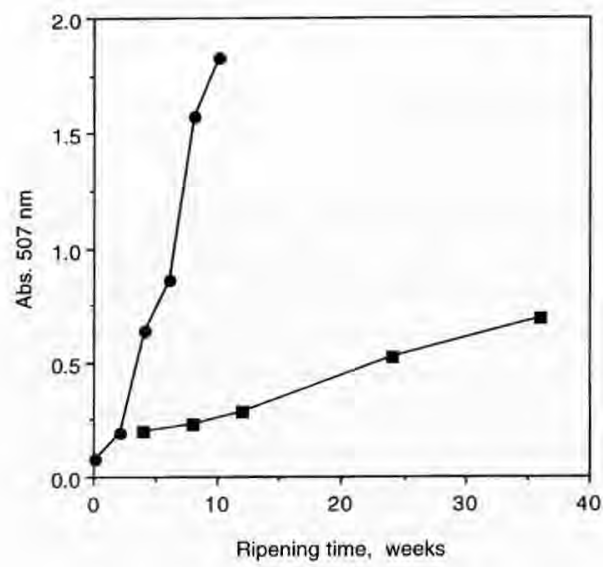

Fig 3. Formation of $\mathrm{Cd}-$ ninhydrin reactive amino groups in Cheddar $(\mathbf{D})$ and an Irish artisanal blue cheese (1) during ripening. Water- (Cheddar) or $\mathrm{pH} 4.6$ (blue)-soluble $\mathrm{N}$ fractions were analyzed by the method of Folkertsma and Fox (1992), modified from Zarmpoutis et al (1996).

Formation des groupes aminés réactifs à la $\mathrm{Cd}$-ninhydrine dans un cheddar $(\boldsymbol{\square})$ et dans un fromage bleu irlandais d'origine artisanale (-) au cours de l'affinage. Les fractions $N$-solubles dans l'eau (cheddar) ou à pH 4,6 (bleu) ont été analysées par la méthode de Folkerstma et Fox (1992), modifiée à partir de Zarmpoutis et al (1996). hydrin technique, is normally expressed as $\mathrm{mg}$ Leu $\mathrm{g}^{-1}$ cheese (by reference to a leucine standard curve) and increases during ripening (fig 3 ). The Cd-ninhydrin procedure of Folkertsma and Fox (1992) is a simple, useful method for estimating total free amino acids in WSEs of cheese and is used routinely in this laboratory; for best results, a set of samples should be analyzed together.

Fluorimetric reagents are also available for quantifying free amino groups. Such techniques are more sensitive than the colorimetric methods described above but have not been used as widely. The HPLC separation of fluorescent derivatives of amino acids and amines (pre-column derivatization) is common (see below).

Fluorescamine (4-phenylspiro [furan-2 $(3 \mathrm{H})$, $1^{\prime}$-phthalan]-3,3'-dione) is used to quantify amino acids and peptides in the picomole range. Fluorescamine, introduced by Weigele et al (1972), reacts with primary amino groups to produce a fluorophore which is assayed at $390 \mathrm{~nm}$ excitation and $475 \mathrm{~nm}$ emission (fig 2c). It reacts at room temperature with water or primary amines, the latter reaction being far faster (Udenfried et al, 1972). Fluorescamine has been used to monitor the hydrolysis of $\kappa$-casein by chymosin (Pearce, 1979; Beeby, 1980) and to quantify acid-soluble proteins, peptides and amino acids in cheese extracts (Creamer et al, 1985). These authors claimed that this reagent gave more consistent results than TNBS.

$o$-Phthaldialdehyde (OPA) reacts with 2-mercaptoethanol and primary amines to form a fluorescent complex (1-alkylthio-2-alkylisoindole; fig 2d), which also absorbs strongly at $340 \mathrm{~nm}$. Church et al (1983), who used OPA to quantify proteolysis in milk protein systems, reported that the method is more accurate than the measurement of $\mathrm{A}_{280}$ and is more convenient than the ninhydrin, TNBS or fluorescamine procedures. Lemieux et al (1990) considered the OPA method to be fast and simple for estimating free amino acids in cheese and if the reaction time was strictly controlled, was less variable than the TNBS method which was considered to be tedious, required heating and the reagent was 
light-sensitive. 9-Fluorenylmethoxy-carbonyl (FMOC) may also have potential for use in cheese analysis as a fluorescent labelling reagent for amino groups.

\section{Enzymatic techniques}

L-Glutamic acid is an important free amino acid in many cheese varieties. An enzyme assay for Glu using flow injection analysis and glutamate dehydrogenase immobilized on activated glass was developed by Puchades et al (1989b); enzyme activity was determined based on the reduction of $\mathrm{NAD}^{+}$. These authors measured free Glu in Cheddar cheese extracts, prepared by the method of Harwalkar and Elliott (1971), which were freeze-dried, resuspended in a phosphate buffer, sonicated, filtered and passed through a Sep-Pak $\mathrm{C}_{18}$ cartridge prior to analysis. This technique was reported to be sensitive, rapid and accurate.

McSweeney et al (1993a) measured free Glu in water extracts of Cheddar using a commercially available assay kit containing glutamate dehydrogenase (Boehringer-Mannheim, Mannheim, Germany). Unlike the procedure of Puchades et al (1989b), in which NADH was measured directly, this procedure uses pig-heart diaphorase to catalyze the reaction of iodonitrotetrazolium chloride with $\mathrm{NADH}$, forming formazan which is assayed spectrophotometrically at $492 \mathrm{~nm}$. The free Glu content of the cheeses increased with age and varied between cheeses with different non-starter populations.

Puchades et al (1990) developed an enzymatic assay with flow injection analysis for total free amino acids in water-soluble extracts of Cheddar cheese, prepared by the method of Harwalkar and Elliott (1971) and filtered through Sep-Pak $\mathrm{C}_{18}$ cartridges. L-Amino acid oxidase (immobilized on glass beads) acted on free amino acids, producing stoichiometric amounts of $\mathrm{H}_{2} \mathrm{O}_{2}$ which then reacted with luminol, a chemiluminescent agent, in the presence of $\mathrm{K}_{3} \mathrm{Fe}(\mathrm{CN})_{6}$, emitting light, which was quantified. This technique was reported to be rapid and reproducible and specific for free amino acids, since peptides, which react to a greater or lesser extent in most other direct-assay procedures for free amino acids, are not degraded by $\mathrm{L}$-amino acid oxidase. However, this enzyme is not equally active on all amino acids; it exhibits high activity on Leu, Phe and Trp but His, Ile and Cys are poor substrates (Puchades et al, 1990).

\section{TECHNIQUES WHICH RESOLVE PEPTIDES}

Although the above non-specific techniques can provide valuable information about the extent of proteolysis and the activity of proteolytic agents, they provide little information on which peptides accumulate or are degraded during ripening. For this reason, techniques which resolve individual peptides have received much attention in recent years.

\section{Electrophoresis}

Since only proteins and large peptides can be visualized by staining, electrophoresis in gel media is limited to monitoring hydrolysis of the parent caseins and the formation and subsequent hydrolysis of the primary proteolytic products of caseins and thus it has been used widely to monitor the primary proteolysis of caseins in cheese. More recently, it has been shown that capillary electrophoresis (CE) has considerable potential for resolving casein-derived peptides with a wide range of molecular masses.

Although classical free-boundary techniques have been used (eg, Lindqvist and Storgards, 1959), the overwhelming majority of electrophoretic analyses of cheese and other dairy products involve zonal electrophoretic techniques in which the electrophoresis buffer is stabilized in various media and the proteins and peptides migrate as discrete bands under the influence of an electric field. Zonal electrophoresis on paper (eg, Lindqvist et al, 1953; Kuchroo and Fox, 1982b), porous cellulose 
acetate or in agar or agarose gels are now rarely used.

Electrophoresis in starch gels, which was first applied to cheese by Melachouris and Tuckey (1966), has been used by some workers to separate caseins or their degradation products in cheese or other products (eg, Vreeman and van Reil, 1990; van den Berg and de Koning, 1990; de Koning et al, 1992) and is quite effective. Although starch gel electrophoresis gives far better results than earlier zonal techniques and Morr (1971) claimed that it gave superior resolution of lower-mobility and cationic peptides than polyacrylamide gels, starch gels are brittle and opaque after staining (Creamer, 1991) and have been largely replaced by polyacrylamide gels.

Electrophoresis in polyacrylamide gels, firrst applied to cheese by Ledford et al (1966), has become the standard technique. The literature was reviewed by Shalabi and Fox (1987), Fox (1989), Creamer (1991), Strange et al (1992), McSweeney and Fox (1993) and Fox et al (1995b). Continuous buffer systems have been used to separate caseins and are reported to have certain advantages over discontinuous buffers (see Creamer, 1991). However, nearly all onedimensional PAGE techniques used in recent studies on cheese have employed discontinuous buffer systems containing urea or sodium dodecylsulphate (SDS) as a dissociating agent. Nondenaturing buffers are not suitable for caseins, although they are used for the analysis of whey proteins.

Sample preparation usually involves dissolving cheese in a buffer (which usually contains a reducing agent, usually 2 -mercaptoethanol) prior to electrophoresis; the solution may be centrifugally defatted, and sucrose or glycerol added to increase the density of the sample to facilitate loading into gel slots (Creamer, 1991).

Direct or indirect staining (followed by destaining using acetic acid; eg, Laemmli, 1970) using Coomassie blue is usually used. Shalabi and Fox (1987), who compared a number of staining techniques for PAGE gels, recom- mended the direct staining procedure of Blakesley and Boezi (1977) with Coomassie blue G250 in the presence of TCA, although amido black was preferred for larger peptides. However, since only relatively large peptides stain under these conditions, the procedure is limited to the detection of the primary degradation products in cheese. O'Sullivan and Fox (1990) found that the peptides in a $10 \mathrm{kDa}$ UF permeate did not stain with Coomassie blue on urea-PAGE, but the retentate of the WSE contained several detectable peptides, as did $2 \%$ TCA-soluble and insoluble fractions of the retentate. Low molecular mass peptides can be visualized using a silver staining technique involving extensive fixing with glutaraldehyde, although such stains have not been used widely to study cheese peptides.

Although urea-containing buffers at acid $\mathrm{pH}$ have been used (eg, Creamer, 1991), the majority of authors have used urea-containing buffers at alkaline $\mathrm{pH}$. Shalabi and Fox (1987) compared several electrophoretic procedures for the analysis of cheese and strongly recommended the stacking gel system of Andrews (1983) in Tris buffers ( $\mathrm{pH} 8.9$ ) containing $4.5 \mathrm{~mol} / \mathrm{L}$ urea. Electrophoresis in alkaline urea-containing gels with direct staining by Coomassie blue G250 is widely used in this and other laboratories to monitor proteolysis in various cheese varieties (fig 4).

Electrophoresis in SDS-containing buffers is a standard technique for protein analysis in general biochemistry; electrophoretic mobility in the presence of SDS is inversely proportional to the logarithm of the molecular weight of the peptide. However, it is less widely used for cheese since the caseins have similar molecular weights (20 000 to 25000 ) and are therefore not as well resolved by SDS-PAGE as by alkaline urea-PAGE. Shalabi and Fox (1987) concluded that SDS-PAGE was inferior to urea-PAGE for cheese analysis, and did not recommend its use. However, Creamer (1991) and Strange et al (1992) considered that SDS-PAGE provides valuable information on cheese ripening, and has been widely used (eg, Marshall et al, 


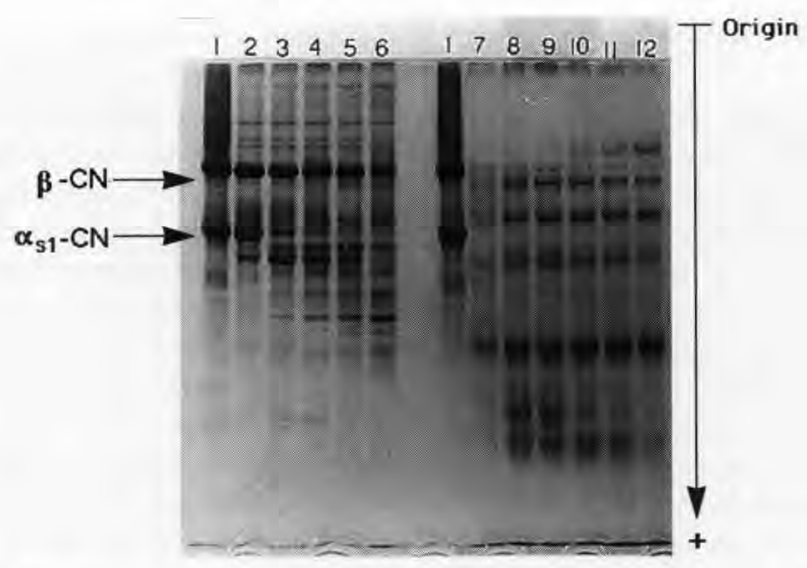

Fig 4. Alkaline urea-polyacrylamide gel electrophoretograms (Andrews, 1983) of casein (lane 1), Cheddar cheeses made from high heat-treated milk $\left(90^{\circ} \mathrm{C} \times 10 \mathrm{~min}\right.$ ) at one day and $1,2,4$ and 6 months of age (lanes 2-6) and water-soluble extracts therefrom (lanes 7-11). Direct staining using Coomassie brilliant blue G250 was by the method of Blakesley and Boezi (1977); (Folkertsma and Fox, unpubl results).

Électrophorégrammes sur gel alcalin urée-polyacrylamide (Andrews, 1993) de caséine (bande 1), de fromages cheddar fabriqués à partir de lait traité à température élevée $\left(90^{\circ} \mathrm{C} \times 10 \mathrm{~min}\right)$ à 1 jour et $1,2,4,6$ mois (bandes 2-6) et leurs extraits solubles dans l'eau (bandes 7-11). Fixation directe par du bleu brillant de Coomassie G250 avec la méthode de Blakesley et Boezi (1977); (Folkertsma et Fox, non publié).

1988; Basch et al, 1989; Bhowmik et al, 1990; Tunick et al, 1993). Shalabi and Fox (1987) considered that the $20 \%$ acrylamide gel system of Tegtmeyer et al (1975) was more satisfactory than the more widely used method of Laemmli (1970), in which $12 \%$ acrylamide gels are used. However, Creamer (1991) reported that $20 \%$ acrylamide gels give poor resolution of the caseins (all caseins migrate as two bands), but are very satisfactory for peptides with molecular weights in the region of 10000 .

Two-dimensional electrophoresis has been used by some authors; eg, Trieu-Cuot and Gripon (1982) used SDS-PAGE in one dimension and isoelectric focusing in the other to study proteolysis in Camembert. Although 2-D electrophoresis may give good resolution, it is timeconsuming and there are difficulties with reproducibility and in obtaining quantitative data (Creamer, 1991). Bican and Spahni (1991) separated peptides in extracts from Appenzeller cheese by thin-layer chromatography in one dimension, followed by electrophoresis at $90^{\circ}$.
Isoelectric focusing (IEF) is a powerful electrophoretic technique for resolving proteins and peptides based on separation according to differences in their isoelectric points. It has been particularly valuable in studies on genetic polymorphism in milk proteins (see Creamer, 1991; and Strange et al, 1992, for references). Some of the applications of IEF in dairy chemistry include the detection of adulteration of ovine milk cheeses with bovine or caprine milks or the study non-bovine caseins (Addeo et al, 1983, 1990a,b; Conti et al, 1988; Moio et al, 1989, 1992; Amigo et al, 1992). Trieu-Cuot and Gripon (1982) used IEF to study the $\mathrm{pH} 4.6$-insoluble fraction of Camembert. Kim and Jimenez-Flores (1994) obtained excellent resolution of milk proteins by preparative IEF followed by urea- or SDS-PAGE. This technique could easily be adapted for the study of proteolysis in cheese. Electrophoresis of cheese peptides has been facilitated by the recent introduction of pre-poured gels and by rapid semi-automated systems such as the Phast system ${ }^{\mathrm{TM}}$ (Pharmacia, Uppsala, 
Sweden; Strange et al, 1992; Van Hekken and Thompson, 1992).

After staining, electrophoretograms are usually recorded photographically, although densitrometry or excision and elution of the stained bands, followed by spectrophotometric quantitation have also been used. Difficulty in obtaining quantitative data is a serious limitation of electrophoresis. Creamer (1991) recommended that several control samples should be included in each gel and that comparisons should be made only between samples on the same gel. $\mathrm{He}$ emphasized that band dimensions are critical for densitometry, and that dye uptake is a function of the protein as well as staining and destaining protocol. However, de Jong (1975) reported that electrophoresis in alkaline urea gels $(\mathrm{pH} 8.9)$, stained with amido black $10 \mathrm{~B}$ and scanned by densitometry, gave good quantitative results.

Identification of peptides produced during cheese ripening has posed difficulties. Peptides can be isolated from PAGE gels by excision of the bands or by electroblotting. The latter technique is preferable because of higher recoveries of protein and because the size of PAGE gels can change on staining which makes accurate excision of unstained regions difficult. Electroblotted peptides can be identified by $\mathrm{N}$-terminal amino acid sequencing (see below), but they are more difficult to analyze by mass spectrometry (MS) because they cannot be stained prior to MS and must be eluted from the blotting matrix. However, the location of all the caseins and some major degradation products (eg, $\gamma$-caseins and $\alpha_{\mathrm{sI}}-\mathrm{CN}$ f24-199) on most PAGE systems is known (Creamer, 1991; Strange et al, 1992). The majority of the peptides in a urea-PAGE electrophoretogram of Cheddar cheese were partially identified (fig 5) by McSweeney et al (1994a). Addeo et al (1995) used immunoblotting (rabbit polyclonal antibodies raised against the caseins and peroxidase-labelled immunoglobulins as secondary antibodies) to detect bands in electrophoretograms of a number of cheese varieties. This technique permitted the identification of the casein from which a number of peptides originated.

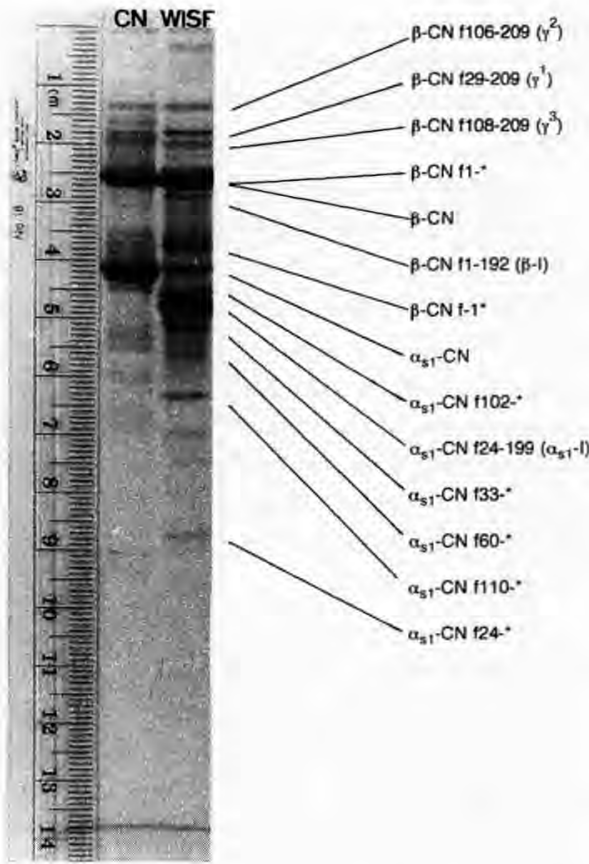

Fig 5. Urea-polyacrylamide gel electrophoretograms of casein $(\mathrm{CN})$ and the water-insoluble fraction (WISF) of 3-month-old Cheddar cheese made with Lactococcus lactis subsp lactis SK11, indicating the positions of the caseins and the N-terminii of the polypeptides identified by McSweeney et al (1994); * undetermined C-terminus.

Électrophorégramme sur gel urée-polyacrylamide de caséine $(C N)$ et de la fraction insoluble dans l'eau (WISF) d'un fromage de cheddar de 3 mois fabriqué avec Lactococcus lactis subsp lactis SKII, avec indication des positions des caséines et des extrémités $N$-terminales des polypeptides identifiés par McSweeney et al (1994); * extrémité C-terminale indéterminée ou non identifiée.

A technique described as high performance electrophoresis chromatography was used by Girardet et al (1994) to resolve component 3 glycoproteins from bovine milk. Proteins were separated in a gel-filled column under the influence of an electric field and separated proteins exiting the bottom of the gel tube were eluted by a continuous flow of buffer and passed through a UV spectrophotometric detector. To 
date, this technique does not appear to have been used to study proteolysis but may have application in the fractionation of large peptides in cheese.

Capillary electrophoresis (CE) resolves peptides in a buffer-filled capillary under the influence of an electric field (fig 6) and as such is a free-boundary technique although, as described below, zonal CE is also possible. CE separates on the basis of the net charge on the peptides, their mass and Stokes' radius (Young et al, 1992) and sometimes on some other property of the peptide (see below). The use of CE in food analysis has been reviewed (Zeece, 1992; Lindeberg, 1996a,b).

Capillary electrophoresis is reported to have great potential for the resolution of complex mixtures of peptides. It has a number of advantages over traditional electrophoretic techniques, including the choice of running buffer and the use of automated, high-performance instrumentation. The composition of running buffer can be changed easily and separation times are relatively short, although only one sample at a time can be analyzed. Unlike conventional electrophoresis, in which proteins and peptides in a gel are visualized by staining, CE uses continuous monitoring by UV absorbance, and potentially by the range of other techniques used for detection in HPLC. UV absorbance allows the detection of small peptides which cannot be visualized by staining and also means that $\mathrm{CE}$ is quantitative, unlike other electrophoretic techniques. It can be used in a number of modes, including free solution capillary electrophoresis, FSCE (although problems have been encountered with interations between peptides and the capillary wall), micellar electrokinetic chromatography (where electrophoresis is performed in the presence of micelles of SDS and peptides partition between the micelles and buffer), capillary isotachophoresis (where the analyte is 'sandwiched' between a leading and terminating electrolyte), capillary gel electrophoresis (which uses a molecular sieving effect), capillary electrochromatography (which uses a capillary packed or coated with a stationary phase) or isoelectric focussing (in which analytes may be eluted from the capillary by a pump after they have reached equilibrium at their $\mathrm{pI}$ ) (Zeece, 1992; Lindeberg, 1996a). There are also CE techniques for resolving racemic mixtures by diasteriomeric interaction of analytes with a chiral mobile or stationary phase (Gordon et al, 1988).

The capital cost of CE instrumentation at present is higher than that of equivalent high performance liquid chromatographs (HPLC), although costs are likely to fall. Sample size in $\mathrm{CE}$ is extremely small and therefore the technique is not suitable for preparative-scale work. $\mathrm{CE}$ may be limited to producing peptide profiles, although $\mathrm{CE}$ coupled with in-line mass

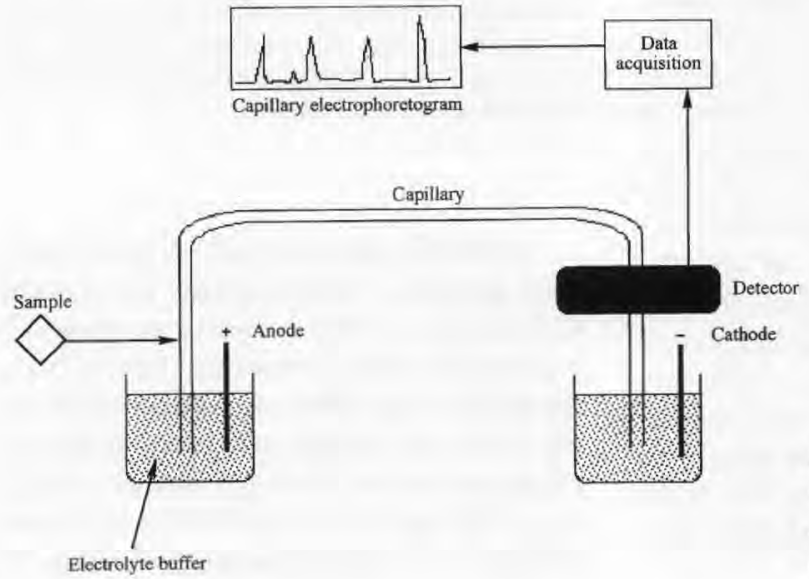

Fig 6. Schematic diagram of a capillary electrophoresis unit. Représentation schématique d'une unité d'électrophorèse capillaire. 


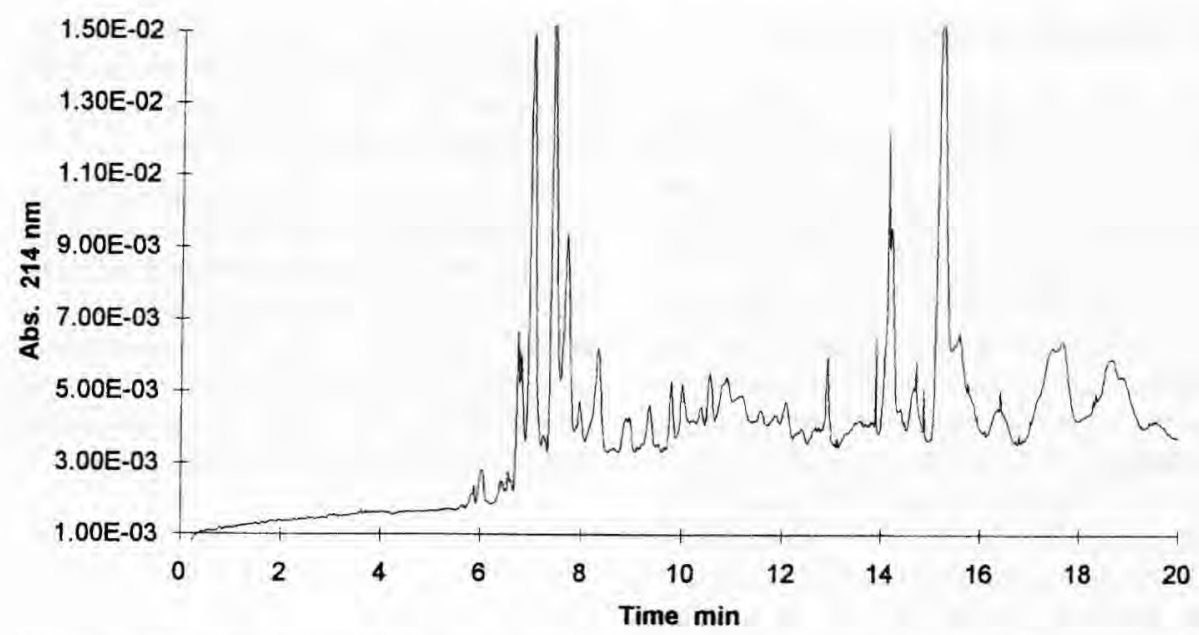

Fig 7. Free solution capillary electrophoretogram of the water-soluble extract (WSE) from a 6-month-old Cheddar cheese made using Lactococcus lactis subsp cremoris SK11 as starter. WSE was dissolved in $1 \mathrm{~mL}$ $8 \%(\mathrm{v} / \mathrm{v}) \mathrm{CH}_{3} \mathrm{CN}$ in water containing $0.1 \%(\mathrm{v} / \mathrm{v})$ trifluoroacetic acid. Electrophoresis was performed using a Beckman Model P/ACE 2050 capillary electrophoresis unit (Beckman, San Ramon, CA, USA) equipped with a $57 \mathrm{~cm}$ fused silica capillary $(50 \mathrm{~cm}$ to detector; internal diameter, $75 \mu \mathrm{m})$. Electrophoretic buffer was $0.1 \mathrm{~mol} / \mathrm{L}$ $\mathrm{Na}$ phosphate buffer, $\mathrm{pH} 2.5$. Electrophoresis was performed at $20 \mathrm{kV}$ and spectrophotometric detection was at $214 \mathrm{~nm}$ (Singh, unpubl results).

Capillaire en solution libre d'un extrait soluble dans l'eau (WSE) de fromage de cheddar de 6 mois fabriqué avec Lactococcus lactis subsp cremoris SKII comme levain. WSE était dissous dans I mL de $\mathrm{CH}_{3} \mathrm{CN}_{\text {à }} 8 \%$ (v/v) dans l'eau, contenant $0,1 \%(\mathrm{v} / \mathrm{v})$ d'acide trifluoracétique. L'électrophorèse était réalisée avec une unité d'électrophorèse capillaire Modèle Beckman P/ACE 2050 (Beckman, San Ramon, CA, États-Unis) équipé d'un capillaire en silice fondue de $57 \mathrm{~cm}$ ( $50 \mathrm{~cm}$ jusqu'au détecteur; diamètre intérieur, $75 \mu \mathrm{m}$ ). Le tampon pour l'électrophorèse était un tampon phosphate de $\mathrm{Na} 0,1 \mathrm{~mol} / \mathrm{L}$, à pH 2,5. L'électrophorèse était réalisée à $20 \mathrm{kV}$ et la détection spectrophotométrique à $214 \mathrm{~nm}$ (Singh, non publié).

spectrometry gives much information on the identity of peptides (Zeece, 1992). It is unlikely that $\mathrm{CE}$ will replace chromatographic and other electrophoretic methods, and it is now viewed as complementing other separation techniques (Lindeberg, 1996a).

$\mathrm{CE}$ has received considerable attention in general food analysis (Zeece, 1992; Lindeberg, 1996a,b). To date, FSCE has been the form of CE most widely used in dairy chemistry. Applications have included ion analysis in milk, milk powders and cheese (Morawski et al, 1993; Schmitt et al, 1993; Prestwell et al, 1995), measurement of hippuric and orotic acids in whey (Tienstra et al, 1992), fractionation of whey proteins (Cifuentes et al, 1993; Otte et al, 1994), measurement of sorbate and benzoate in cheese slices and dips (Pant and Trenerry, 1995), detection of chloramphenicol in milk (Blais et al, 1994) and quantification of seleno amino acids in human milk (Michalke, 1995).

The potential of this technique for isolating peptides from cheese was demonstrated by Zeece (1992), who separated peptides in a tryptic digest of native and dephosphorylated $\alpha_{\mathrm{s1}}{ }^{-}$and $\beta$-caseins. The authors are aware of a number of laboratories investigating the potential of $\mathrm{CE}$ to study proteolysis in cheese, although no reports of capillary electrophoretograms of cheese peptides appear to have been published to date. A free-solution capillary electrophoretogram of a water extract from a mature Cheddar cheese is shown in figure 7 (Singh, unpubl results). 


\section{Chromatography of cheese peptides}

Paper chromatography (PC) was used by many early workers to quantify free amino acids in cheese (eg, Kosikowsky, 1951a; Storgards and Lindqvist, 1953; Clemens, 1954) or to study cheese peptides (eg, O' Keeffe et al, 1978; Kuchroo and Fox, 1982b, 1983a). Paper chromatography is cheap and straightforward, but suitable only for assessing the complexity of systems containing only small peptides (Ardö and Gripon, 1991) and has been largely superseded by other techniques. Thin layer chromatography (TLC) on silica gel, using different solvents, eg, $n$-propanol/water $(70: 30, \mathrm{v} / \mathrm{v})$ or $n$-propanol/acetic acid/water $(5: 1: 3)$, has been used to characterize peptides in cheese fractions (Kuchroo and Fox, 1982b, 1983a, b; Edwards and Kosikowski, 1983; Visser et al, 1983b). Ninhydrin is usually used to develop the plates, although UV fluorescence of the spots was used by Edwards and Kosikowski (1983). Preparative TLC has been used to isolate bitter peptides from Cheddar (Edwards and Kosikowski, 1983). Bican and Spahni (1991) combined TLC on silica gel plates (chloroform/ammonia/ethanol as solvent) with electrophoresis in the perpendicular dimension to resolve peptides in Appenzell cheese: plates were developed by spraying with fluorescamine and viewed under UV light. TLC is a simple, straightforward method for separating peptides and is normally superior to paper chromatography, although Kuchroo and Fox (1983a) obtained better resolution of peptides by PC than by TLC. Both paper and TLC chromatographic techniques are now rarely used.

Column chromatography on silica gels (eg, Visser et al, 1975), metal chelating media (eg, $\mathrm{Cu}$-Sephadex; Ney, 1985; Mojarro-Guerra et al, 1991) or on hydrophobic interaction media (eg, Kuchroo and Fox, 1983a; Visser et al, 1983b) have been used to fractionate peptides from cheese or casein hydrolysates. Mulvihill and Fox (1979) used phosphocellulose to fractionate peptides produced from $\alpha_{\mathrm{s} 1}$-casein by chymosin, but this medium does not appear to have been used for cheese. A few authors have used the molecular sieving properties of cation-exchanger Dowex 50 resins to fractionate cheese peptides (eg, Tokita and Nakanishi, 1962; Huber and Klostermeyer, 1974; Biede and Hammond, 1979).

Mooney and Fox (unpubl results) fractionated peptides in the water-insoluble fraction of Cheddar cheese by high-performance hydrophobic interaction chromatography on a Phenyl-Sepharose column in a $0.48 \mathrm{~mol} / \mathrm{L} \mathrm{Na}$ phosphate buffer, $\mathrm{pH} 6.3$, containing $2.5 \mathrm{~mol} / \mathrm{L}$ urea; elution was by means of a gradient from 0.48 to $0.037 \mathrm{~mol} / \mathrm{L} \mathrm{Na}$ phosphate (fig 8 ).

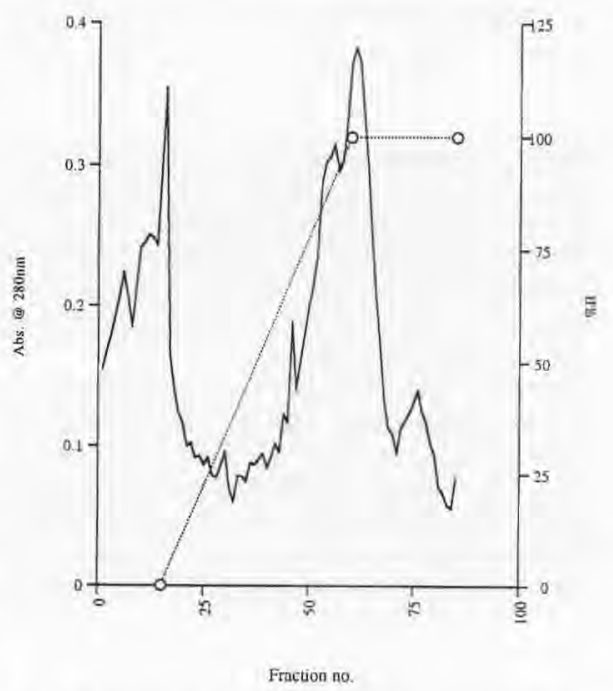

Fig 8. Hydrophobic interaction chromatogram of the water-insoluble fraction of a 20-week-old Cheddar cheese on Phenyl-Sepharose High Performance TM (Pharmacia, Uppsala, Sweden). Elution was by a gradient of Na phosphate buffer from 0.48 (buffer A) to $0.037 \mathrm{~mol} / \mathrm{L}$ (buffer B), $\mathrm{pH} 6.3$ to 6.6 , containing $2.5 \mathrm{~mol} / \mathrm{L}$ urea and $0.1 \%$ dithiothreitol. Flow rate was $1 \mathrm{~mL} / \mathrm{min}$ and UV spectrophotometric detection was at $280 \mathrm{~nm}$ (Mooney and Fox, unpublished).

Chromatogramme d'interactions hydrophobes de la fraction insoluble dans l'eau d'un fromage de cheddar de 20 semaines sur Phenyl-Sepharose High Performance ${ }^{\mathrm{TM}}$ (Pharmacia Uppsala, Suède). L'élution était réalisée avec un gradient de tampon phosphate de Na de 0,48 (tampon A) à 0,037 mol/L (tampon B), pH 6,3 à 6,6, contenant 2,5 mol/L d'urée et $0,1 \%$ de déthiothreitol. La vitesse d'écoulement était de $1 \mathrm{~mL}$ min et la détection en spectrophotométrie $U V$ était à $280 \mathrm{~nm}$ (Mooney et Fox, non publié). 
The most popular forms of chromatography for analysis of cheese peptides have been ionexchange and size-exclusion techniques and reverse-phase high performance liquid chromatography (RP-HPLC).

Molecular weights may be estimated by sizeexclusion chromatography on a calibrated column. The majority of workers have used Sephadex ${ }^{\text {TM }}$ gels (Pharmacia, Uppsala, Sweden) of various pore sizes. Cheese preparations chromatographed have included cheese or high molecular weight peptides (Lindqvist, 1962; Tokita and Hosono, 1968; Creamer and Richardson, 1974; Foster and Green, 1974; Gripon et al, 1975), water-soluble or similar extracts (Nath and Ledford, 1973; Desmazeaud et al, 1976; O'Keeffe et al, 1976; Santoro et al, 1987), dialyzable or UF permeable fractions from water extracts (Kuchroo and Fox, 1983b; Singh et al, 1994, 1995) or PTA-soluble peptides (González de Llano et al, 1987, 1991).

Numerous eluents have been used, although water and dilute buffers are most common and chromatograms are usually quantified by spectrophotometry at UV wavelengths. Generally, $280 \mathrm{~nm}$ is used but for fractions containing smaller peptides, absorbance of the carbonyl group in the peptide bond at a lower wavelength, eg, $220 \mathrm{~nm}$ (Foster and Green, 1974; Green and Foster, 1974) is preferable, since small peptides may not contain aromatic residues. Measurement of the amino group by reaction with ninhydrin (eg, Gripon et al, 1977) or some other reagent is an alternative.

Low-pressure, preparative HPLC techniques (eg, FPLCTM, Pharmacia, Uppsala, Sweden) on size-exclusion media have simplified this form of chromatography. Wilkinson et al (1992) resolved press juice from Cheddar by high-performance size-exclusion chromatography (HPSEC) on a Superose-12 column; changes in the peptide profile during ripening were evident. HPSEC on a Superose- 12 column is also valuable for characterizing peptides in various fractions from Cheddar (Breen et al, 1995) and is suitable for preparing peptide fractions. Haasnoot et al (1989) fractionated peptides in Gouda cheese solubilized in urea by HPSEC on TSK 3000 SW and 2000 SW columns in series. This technique gave some information about primary and secondary proteolysis during ripening, but these authors considered that the size-exclusion columns were not suitable for the separation of the components present in water- or TCA-soluble fractions. Vijayalakshmi et al (1986) reported an interesting method for resolving peptides of molecular mass between 250 and $6000 \mathrm{Da}$ on a TSK-SW 2000 column using $50 \mathrm{mmol} / \mathrm{L}$ phosphate buffer containing $0.1 \%$ trifluoroacetic acid and $35 \%$ methanol as mobile phase. HPSEC has also been used to characterize caseins, whey proteins and peptides derived therefrom (van Hooydonk and Olieman, 1982; Bican and Blanc, 1982; Vreeman et al, 1986).

Ion-exchange chromatography is used widely to fractionate milk proteins but has only had limited use in cheese analysis (Fox, 1989). Anion-exchange chromatography on diethylaminoethyl (DEAE)-cellulose was used to isolate $\alpha_{s 1}-C N$ f24-199 ( $\alpha_{s 1}$-I casein) from Cheddar (Creamer and Richardson, 1974) and to fractionate water-insoluble peptides (Breen, 1992; McSweeney et al, 1994a; Mooney and Fox, unpubl results) and the 2\% TCA-soluble and insoluble fractions of a $10 \mathrm{kDa}$ UF retentate of a water-soluble extract of Cheddar (O'Sullivan and Fox, 1990). High-performance ion-exchange columns (eg, Mono-S ${ }^{\mathrm{TM}}$ or Mono$\mathrm{Q}^{\mathrm{TM}}$, Pharmacia) give better resolution of bovine milk proteins than classical chromatography on DEAE-cellulose (Barrefors et al, 1985; St Martin and Paquin, 1990). Anion exchange chromatography of a urea solution of Gouda cheese on a Mono- $Q^{\mathrm{TM}}$ column was used by Haasnoot et al (1989) to study proteolysis. It was concluded that the ratio $\gamma$ - to $\beta$-casein peak areas is a good indicator of the maturity of Gouda cheese ripened for up to about 10 months, whereas the ratio of the peak areas representing $\alpha_{\mathrm{s} 1}$-casein and $\alpha_{\mathrm{s} 1}-\mathrm{CN}$ f 24-199 was a suitable index for very young cheeses (< four weeks). Urea-containing buffers have usually been used to dissolve cheese prior to chromatography and chromatograms are monitored by $\mathrm{A}_{280}$, although 
ninhydrin has been used by some workers (Fox et al, 1995b).

In our experience, anion-exchange chromatography on DEAE-cellulose or equivalent high-performance medium (eg, Mono- $\mathrm{Q}^{\mathrm{TM}}$ ) in urea-containing buffers is very suitable for the fractionation of large casein-derived peptides. This form of chromatography is used routinely in this laboratory to fractionate the water-insoluble peptides from cheese (fig 9; Mooney and Fox, unpubl results). Fractions from the anionexchange chromatogram can be collected and analyzed by urea-PAGE.

The introduction of high performance ionexchange chromatography (HPIEC) and HPSEC

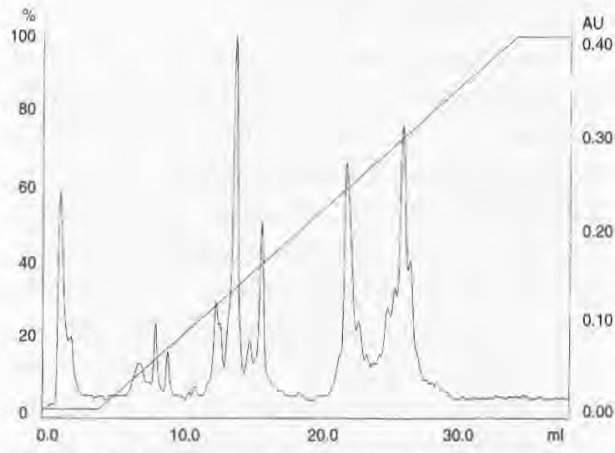

Fig 9. High-performance anion-exchange chromatogram of the water-insoluble fraction (WISN) of Cheddar cheese on a Mono-Q 5/5 column (Pharmacia, Uppsala, Sweden). WISN ( $500 \mu \mathrm{L}$ of $15 \mathrm{mg}$ WISN $\mathrm{mL}^{-1}$ dissolved in $50 \mathrm{mmol} / \mathrm{L}$ Tris- $\mathrm{HCl}$ buffer, $\mathrm{pH} 8.0$, containing $4.5 \mathrm{~mol} / \mathrm{L}$ urea and $1.2 \times 10^{-3} \mathrm{~mol} / \mathrm{L}$ dithiothreitol, DTT) was applied to the column and eluted at a flow rate of $1 \mathrm{~mL} \mathrm{~min}^{-1}$ using the above buffer containing $8 \times 10^{-4} \mathrm{~mol} / \mathrm{L}$ DTT and an $\mathrm{NaCl}$ gradient $(0$ to $0.5 \mathrm{~mol} / \mathrm{L})$. UV spectrophotometric detection was at $280 \mathrm{~nm}$ (Mooney and Fox, unpubl results).

Chromatogramme d'échanges d'anion haute performance de la fraction insoluble dans l'eau (WISN) de fromage cheddar sur colonne Mono-Q $5 / 5$ (Pharmacia Uppsala, Suède). WISN ( $500 \mu \mathrm{L}$ de $15 \mathrm{mg}$ de WISN $m L^{-I}$ dissous dans un tampon Tris- $\mathrm{HCl}$ à $50 \mathrm{mmol} / \mathrm{L}$, $\mathrm{pH} 8,0$, contenant $4,5 \mathrm{~mol} / \mathrm{L}$ d'urée et $1,2 \times 10^{-3} \mathrm{~mol} / \mathrm{L}$ de dithiotreitol, DTT) était injecté dans la colonne et élué avec une vitesse d'écoulement de $1 \mathrm{~mL}^{\mathrm{min}-1}$, en utilisant le tampon ci-dessus contenant $8 \times 10^{-4} \mathrm{~mol} / \mathrm{L}$ DTT et un gradient $\mathrm{NaCl}(0$ à $0,5 \mathrm{~mol} / \mathrm{L})$. Détection en spectrophotométrie UV à $280 \mathrm{~nm}$ (Mooney et Fox, non publié). has greatly reduced the workload involved in these forms of column chromatography, while increasing speed and reproducibility. Thus, it seems likely that these techniques will achieve more widespread application in the future for monitoring proteolysis in cheese.

Reverse phase-HPLC has been used extensively to characterize peptides in casein hydrolyzates (eg, Le Bars and Gripon, 1989; McSweeney et al, 1993b) and the technique is also very valuable for resolving shorter peptides in cheese fractions. Water-soluble extracts have usually been used for RP-HPLC analysis (eg, Cliffe and Law, 1991; González de Llano et al, 1991; McSweeney et al, 1993a) but other fractions have also been studied, including $\mathrm{pH} 4.6$ soluble and -insoluble extracts (eg, Kaminogawa et al, 1986; Christensen et al, 1989), $10 \mathrm{kDa}$ UF permeate (Singh et al, 1994), 70\% ethanol soluble and insoluble fractions (Zarmpoutis et al, 1996) and fractions from size-exclusion chromatography (Cliffe et al, 1993).

Gradient elution with water/acetonitrile (eg, Amantea et al, 1986) or water/methanol (eg, Cliffe et al, 1993) is usually used; but isocratic conditions using a phosphate buffer as eluent have also been used by some workers (eg, Pham and Nakai, 1984). TFA is the most widely used ion-pair reagent. Detection is generally by UV spectrophotometry, usually at a wavelength in the range of 200-230 $\mathrm{nm}$ (which measures the carbonyl in the peptide bond), although $280 \mathrm{~nm}$ has been used in cases where larger peptides, which are more likely to contain aromatic residues, are expected (eg, Christensen et al, 1989). Fluorescence detection has also found limited use (eg, González de Llano et al, 1991). Reverse-phase chromatography on a semipreparative $\mathrm{C}_{2} / \mathrm{C}_{18}$-coated silica was used by Cliffe et al (1989) to fractionate cheese peptides.

Although RP-HPLC essentially remains a research tool, Smith and Nakai (1990) discussed its potential for the routine assessment of cheese quality. Difficulties remain with the interpretation of RP-HPLC data and the development of a solvent system which will permit tasting of the fractions (Ardö and Gripon, 1991). As var- 
ious columns, elution conditions and detection wavelengths have been used, comparison of chromatograms from different studies is difficult. Although RP-HPLC is widely used to purify individual peptides from cheese (eg, Singh et al, 1994, 1995, 1996), the authors caution against the identification of most peptides in chromatograms based solely on their retention time. However, two major peptides, $\alpha_{\mathrm{s} 1}-\mathrm{CN}$ fl- 9 and $\mathrm{fl}-13$ (produced by the action of $\mathrm{LaC}$ tococcus cell envelope-associated proteinase on $\alpha_{s 1}-\mathrm{CN} \mathrm{f1-23}$, which is produced rapidly by chymosin) are characteristic of the chromatograms of Cheddar cheese (fig 10a).

RP-HPLC is a very valuable technique for the resolution of water-soluble peptides in cheese. It has been our experience that watersoluble extracts resolve well on $\mathrm{C}_{8}$ wide-pore ( $300 \AA$ ) columns with a shallow acetonitrile/ water gradient with TFA as the ion-pair reagent (eg, McSweeney et al, 1994b). However, due to the complexity of the WSE from many cheeses, it is often desirable to fractionate the WSE. Chromatography of $10 \mathrm{kDa}$ UF permeates is adequate but time-consuming. For this reason, we now fractionate with $70 \%$ ethanol prior to RP-HPLC. Typical chromatograms of the ethanol-soluble and insoluble fractions from Cheddar are shown in figure $10 \mathrm{a}, \mathrm{b}$ (Tobin et al, unpubl results).

Elution of peptides from $\mathrm{a} \mathrm{C}_{18}$-reverse phase cartridge using a stepwise acetonitrile gradient was used by Singh et al $(1994,1995)$ to resolve peptides in a fraction obtained by size-exclusion chromatography of a $10 \mathrm{kDa}$ UF permeate of a WSE of Cheddar cheese, and by Bican and Spahni (1993) to sub-fractionate extracts of Swiss-type cheees. This technique gave considerably simpler sub-fractions from which individual peptides were isolated.

Two-dimensional HPLC (2D-HPLC) was used by Lagerwerf et al (1995) to fractionate the peptides in the WSE of Cheddar cheese; the eluate from the first dimension (ion-exchange) was directed to a reverse-phase column $\left(\mathrm{C}_{18}\right)$. The resolution obtained was impressive, although increased equipment requirements and long analysis times $(\sim 10 \mathrm{~h})$ are likely to militate against the widespread use of 2D-HPLC.

\section{QUANTIFICATION OF FREE AMINO ACIDS AND THEIR DEGRADATION PRODUCTS}

Ultimately, the hydrolysis of caseins by the combined action of proteinases and peptidases in cheese leads to the liberation of free amino acids which are considered to be important flavour compounds in many cheeses; their concentration varies widely with variety. In addition, volatile compounds formed from amino acids by decarboxylation, deamination, transamination and other transformations can make substantial contributions to cheese flavour (see Fox et al, 1995a).

It is generally necessary to deproteinize samples prior to amino acid analysis to reduce interference from peptides; reagents used have included sulphosalicylic acid (Reiter et al, 1969; Omar, 1984), ethanol (Visser, 1977; Polychroniadou and Vlachos, 1979), picric acid (Weaver et al, 1978; Shindo et al, 1980), TCA (Zarmpoutis et al, 1996) or $\mathrm{Ba}(\mathrm{OH})_{2} / \mathrm{ZnSO}_{4}$ (Hickey et al, 1983). An internal standard (eg, norleucine) is normally added to facilitate quantitation of amino acids.

Early attempts to quantify free amino acids in cheese used paper chromatography developed using ninhydrin (eg, Kosikowsky, 1951a, b) but such techniques were only semi-quantitative. Likewise, classical ion-exchange column chromatography (eg, Mabbitt, 1955, who used Dowex-50 resin) is now obsolete and has been superseded by automated amino acid analyzers, which are less laborious.

Dedicated amino acid analyzers based on ion-exchange chromatography are used widely and have greatly facilitated the analysis of free amino acids in cheese, which is now relatively simple, accurate, quantitative and requires litthe sample preparation. Amino acids are usually detected by post-column derivatization, often using ninhydrin. Recent studies in which this 

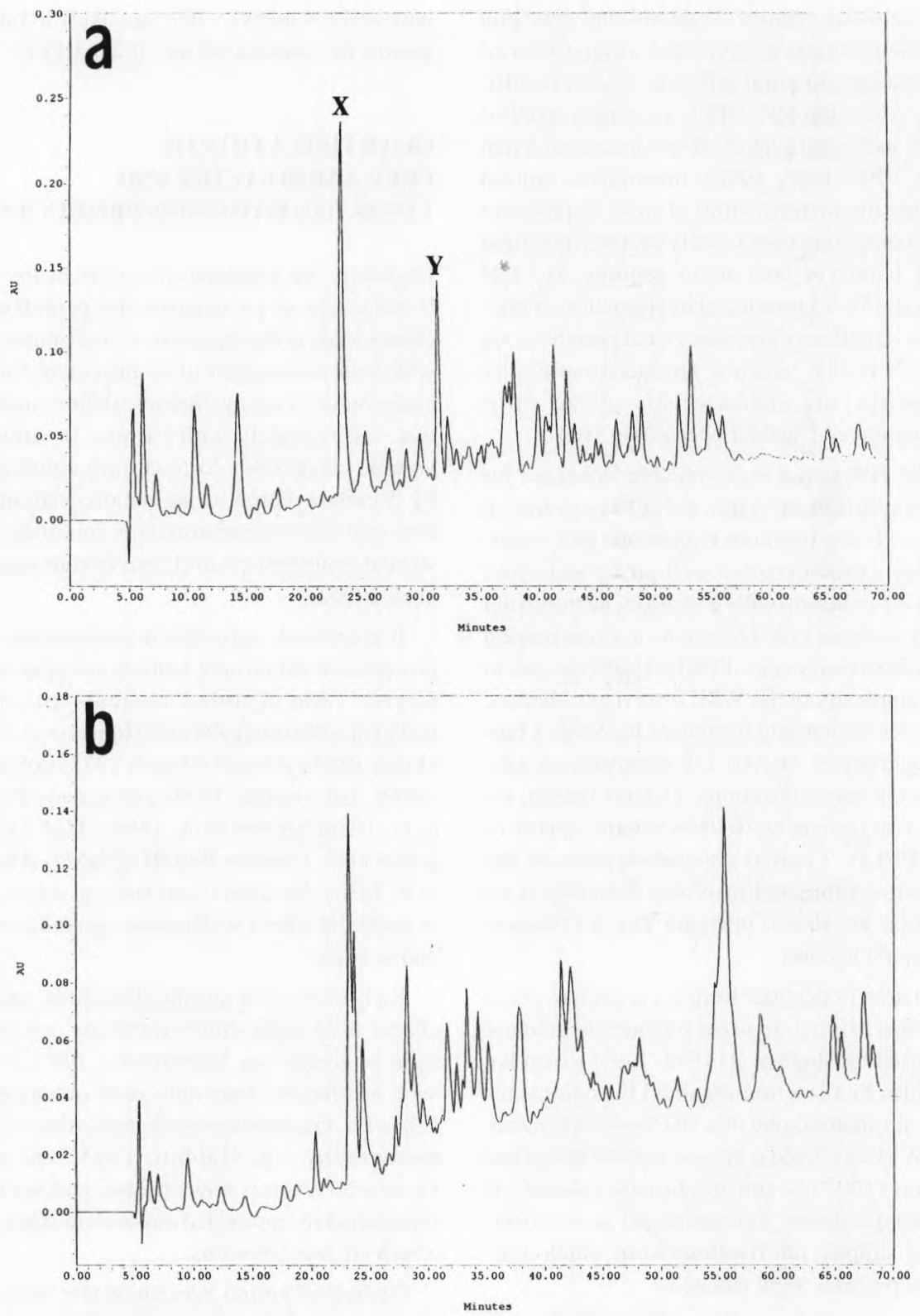

Fig 10. Reverse-phase $\left(\mathrm{C}_{8}\right)$ high-performance liquid chromatograms of the $70 \%$ ethanol-soluble (a) and insoluble (b) fractions of the water-soluble fraction of a 9-month-old Cheddar cheese. The locations of the peptides $\alpha_{\mathrm{s} 1}-\mathrm{CN}$ f1-9 (X) and f1-13 (Y) are indicated (Tobin et al, unpubl results).

Profil obtenu par chromatographie liquide haute performance en phase inverse $\left(C_{8}\right)$ des fractions $(a)$ solubles dans l'éthanol à $70 \%$ et (b) insolubles de la fraction soluble dans l'eau d'un fromage de cheddar de 9 mois. Les localisations des peptides $\alpha_{s I}$ CN fl-9 (X) et fl-13(Y) sont signalées (Tobin et al, non publié). 
technique was used include those by Ardö and Gripon (1995) and Zarmpoutis et al (1996).

Reverse-phase HPLC of pre-column-derivatized fluorescent-labelled amino acids is increasingly being used to measure free amino acids in cheese, and has the advantage of using standard equipment and being amenable to automated derivatization. Amino acids have been separated as their dansyl (eg, Polo et al, 1985), OPA (eg, Ramos et al, 1987; Bütikofer et al, 1991) or FMOC (Bütikofer et al, 1991) derivatives. Bütikofer et al (1991) compared the results of amino acid analysis of an acid hydrolysate of cheese proteins by pre-column derivatization with OPA or FMOC, followed by RP-HPLC, with the results obtained using an amino acid analyzer fitted with an ion-exchange column and using post-column derivatization with ninhydrin. HPLC gave rapid, simple and sensitive determination of amino acids and yielded narrower, better-resolved peaks with shorter retention times and a more stable baseline. Although the HPLC method used had a slightly lower repeatability for some amino acids, it had good reproducibility and correlated well with ionexchange chromatography.

Amino acids can be also quantified by gas chromatography (GC) after derivatization with heptafluorobutyric anhydride (HFBA) to yield $n$-heptafluorobutyryl isobutyl derivatives. Capilliary GC is most suitable (eg, Wood et al, 1985; Laleye et al, 1987; Bertacco et al, 1992). This technique is reported to give good recovery of added amino acids; all protein amino acids can be resolved on a single chromatogram, and speed and accuracy are comparable to those of automated amino acid analyzers and at far lower equipment costs. The technique has good reproducibility and high accuracy, although the coefficients of variation for Met and Gly are somewhat high (Bertacco et al, 1992). However, GC has not been used as widely as alternative techniques.

Ammonia is produced by deamination of amino acids, and techniques for its quantification have been discussed above. Amines in cheese may be quantified by RP-HPLC using pre-col- umn derivatization (eg, Bütikofer et al, 1990). Gas chromatography with mass spectrometric detection (GC-MS) allows the quantification and identification of volatiles from cheese (eg, Urbach, 1993), including those resulting from amino acid catabolism. A discussion of GC-MS is outside the scope of this review.

\section{A FRACTIONATION SCHEME FOR CHEESE PEPTIDES}

The peptide system in most cheese varieties is extremely complicated. For example, $>200$ peptides have been isolated and identified from the WSE of Cheddar (Singh et al, 1994, 1995, 1996). The detailed study of proteolysis in cheese often requires that peptides in the initial extract be fractionated by a combination of the techniques discussed above. A number of fractionation schemes have been proposed (Kuchroo and Fox, 1983b; Aston and Creamer, 1986; Fox, 1989; O'Sullivan and Fox, 1990; Cliffe et al, 1993; Singh et al, 1994, 1995, 1996; Breen et al, 1995). The scheme used at present in this laboratory is shown in figure 11. This fractionation scheme was developed for Cheddar cheese and may need to be modified for other varieties.

\section{ISOLATION AND IDENTIFICATION OF INDIVIDUAL PEPTIDES}

Individual small peptides are usually isolated by RP-HPLC. Fractions of eluate may be collected and freeze-dried. It is desirable to check the homogeneity of fractions by re-chromatography under the same or preferably different elution conditions. Peptides eluted in saltcontaining buffers may be desalted by rechromatography using an acetonitrile or methanol gradient, the components of which are easily volatilized.

In our experience, RP-HPLC does not adequately resolve larger casein-derived peptides. Such peptides may be resolved by PAGE and isolated by electroblotting onto a suitable mem- 
brane (eg, polyvinylidine difluoride; McSweeney et al, 1994a; Singh et al, 1995). Alternatively, unstained regions of the gel may be excised, and peptides extracted from the macerated gel pieces by electrophoresis. However, the precise location of peptides on unstained gels may be difficult since they cannot be compared directly with stained gels, the dimensions of which change on staining. The $\mathrm{N}$-terminal sequence (see below) of electroblotted peptides can be determined readily, but it is necessary to remove peptides from the blotting membrane prior to mass spectrometric analysis.

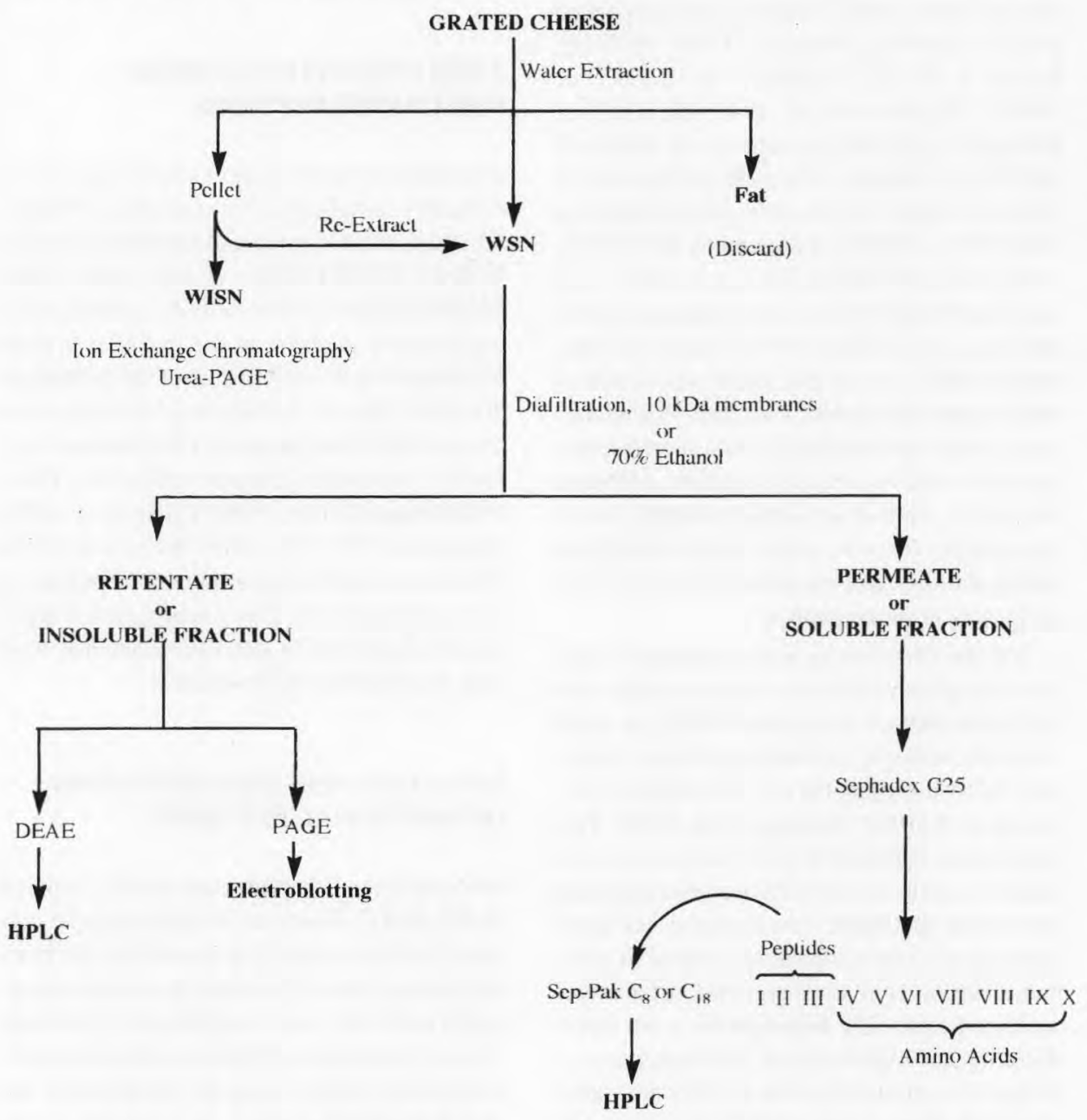

Fig 11. Fractionation scheme for cheese $\mathrm{N}$ (modified from Fox et al, 1995). WSN: water-soluble N; WISN: water-insoluble N; DEAE: ion-exchange chromatography on DEAE-cellulose; PAGE: alkaline urea-polyacrylamide gel electrophoresis; HPLC: reverse-phase $\left(\mathrm{C}_{8}\right)$ high performance liquid chromatography.

Schéma de fractionnement de l'azote ( $N$ ) du fromage (modifié à partir de Fox et al 1995). WSN : azote soluble dans l'eau; WISN : azote non soluble dans l'eau; DEAE: chromatographie échangeuse d'ions sur cellulose $D E A E$; PAGE : électrophorèse sur gel alcalin urée-polyacrylamide; HPLC : chromatographie liquide haute performance en phase inverse $\left(C_{8}\right)$. 
The amino acid composition of a peptide, determined after hydrolysis, can provide useful information as to its identity (eg, Kaminogawa et al, 1986). Computer software can be written (eg, Petrilli, 1982) or is available from commercial sources to aid in locating a peptide of a given amino acid composition in the protein chain. However, more than one casein-derived peptide may have the same amino acid composition and thus identification of peptides in a complex mixture from their amino acid composition, alone is not recommended. Identification of the $\mathrm{N}$-terminal residue or sequence (eg, Visser et al, 1977; González de Llano et al, 1991) improves the probability of correct identification of peptides of a given composition.

Amino acid sequencing (either manual, eg, Mojarro-Guerra et al, 1991 or automated, eg, McSweeney et al, 1994a; Singh et al, 1994, 1995,1996 ) by Edman degradation can also be used to identify peptides. However, unless the peptide is relatively short, it may not be possible to determine its full sequence. The $\mathrm{N}$-terminal sequence (5-7 residues) is normally adequate to locate the origin of a peptide in the caseins, but other techniques must be used to determine its length. $\mathrm{C}$-terminal sequencing (eg, liberation of amino acids over time by carboxypeptidase $\mathrm{Y}$, eg, McSweeney et al, 1993b) could be used for this purpose but is not popular. Mass spectrometry (MS) is more convenient for identifying peptides of known N-terminal sequence (eg, Singh et al, 1994, 1995, 1996), although mass analysis alone is often insufficient to identify peptides since different casein-derived peptides can have the same amino acid composition (and hence mass). An interesting application of MS involves determining the residual mass of a peptide after each cycle of a manual Edman degradation. The mass of the residue $\left(M_{\mathrm{r}}\right)$ released can be calculated from $M_{\mathrm{r}}=M_{n}-M_{n-1}$, where $M_{n}$ and $M_{n-1}$ are the masses of the peptide before and after removal of the $\mathrm{N}$-terminal residue, which can thus be identified. Sequencing of the first few amino acids, coupled with its mass, permits precise identification of the peptide. Such an approach has been used to identify pep- tides in Cheddar cheese (Gouldsworthy et al, 1996). Most MS techniques used to identify peptides involve the production of ions of the intact peptide. However, if high energies are used, the peptide is fragmented and the masses obtained are those of the resulting fragments. Cyclic dipeptides and $\gamma$-glutamyl peptides have been identified using this technique (Roudot-Algaron et al, 1993, 1994), which yields more information on the structure of the compound under study than just its mass; it is likely to be useful for studying very short peptides or those with an unusual structure.

\section{STRATEGIES FOR ASSESSING PROTEOLYSIS}

The choice of a technique for assessing proteolysis in cheese depends on a number of factors, including availability of equipment and resources, cheese variety and objectives of the study. Since proteolysis is one of the principal biochemical events during cheese ripening, it is desirable to include an assay for proteolysis in most cheese ripening studies. The formation of soluble $\mathrm{N}$ or liberation of reactive groups may be adequate if a detailed investigation of proteolysis is not warranted. However, if a thorough study of proteolysis is deemed worthwhile, it is desirable to consider the entire process from the initial hydrolysis of the caseins to the development of free amino acids and to use techniques which resolve individual peptides.

Certain cheese varieties have characteristics which influence the choice of method. The increase in $\mathrm{pH}$ of mould-ripened varieties means that $\mathrm{pH} 4.6$ buffers are more suitable as primary extractants than water. Likewise, since ammonia is a major product of proteolysis in mould and bacterial surface-ripened varieties, it may be desirable to quantify ammonia. The rate and/or pattern of proteolysis may be influenced by location within a cheese, eg, surface-ripened or young, brine-salted cheeses. A suitable sampling scheme should take account of such differences. 
If one or more of the proteolyic agents is modified in a cheese, then the methods used to study proteolysis should be chosen so as to emphasize the level of proteolysis caused by that agent. For example, if the influence of coagulant is studied, the formation of WSN and peptide profiles by urea-PAGE are suitable methods. Since the coagulant does not produce free amino acids, their determination does not directly measure the contribution of the coagulant. In contrast, since the contribution of cheese microflora (natural or modified) to cheese ripening is mainly in the production of short peptides and free amino acids, RP-HPLC and amino acid analysis are likely to be most effective. However, it is also important to include some index of primary proteolysis (eg, PAGE) to ensure that it is typical.

In this laboratory, routine assessment of proteolysis in Cheddar cheese during ripening involves the determination of WSN (Kuchroo and Fox, 1982a) and peptide profiles of the cheese and WSEs therefrom by alkaline urea-PAGE (Blakesley and Boezi, 1977; Andrews, 1983). These assays provide important information on primary proteolysis. Watersoluble extracts are fractionated using $70 \%$ ethanol and the soluble and insoluble fractions analyzed by RP-HPLC (C $C_{8}$; Singh et al, 1995). The $70 \%$ ethanol-insoluble fraction can also be analyzed by urea-PAGE. Total free amino acids are determined using the $\dot{C}$-ninhydrin assay (Folkertsma and Fox, 1992) and individual amino acids by an automated amino acid analyzer with post-column derivatization using ninhydrin. This strategy provides information on the level and type of proteolysis from the initial hydrolysis of the caseins to the liberation of free amino acids; and is suitable for most internal, bacterially-ripened cheese varieties.

\section{ACKNOWLEDGMENT}

The authors wish to express their thanks to A Cahalane for assistance in preparing the manuscript.

\section{REFERENCES}

Abdel Baky AA, Abo Ella WM, Aly ME, Fox PF (1987) Improving the quality of Ras-type cheese made from recombined milk containing high levels of total solids. Food Chem 26, 175-188

Addeo F, Chianese L, Di Luccia A, Petrilli P, Mauriello R, Anelli G (1983) Identification of bovine casein variants by gel isoelectric focusing. Milchwissenschaft 38, 586-588

Addeo F, Moio L, Chianese L, Stingo C, Di Luccia A (1990a) Improved procedure for detecting bovine and ovine milk mixtures in cheese by isoelectric focusing of para-K-casein. Milchwissenschaft 45 , 221-224

Addeo F, Moio L, Chianese L, Stingo C, Resmini E, Berner I, Krause D, Di Lucci A, Bocca A (1990b) Use of plasmin to increase the sensitivity of the detection of bovine milk in ovine cheese by gel isoelectric focusing of $\gamma^{2}$-caseins. Milchwissenschaft 45, 708-711

Addeo F, Chianese L, Salzano A, Sacchi R, Cappuccio U, Ferranti P, Malorni A (1992) Characterization of the $12 \%$ trichloroacetic acid-soluble oligopeptides of Parmigiano-Reggiano cheese. J Dairy Res 59, 401-411

Addeo F, Chianese L, Sacchi R, Spagna Musso S, Ferranti P, Malorni A (1994) Characterization of the oligopeptides of Parmigiano-Reggiano cheese soluble in $120 \mathrm{~g}$ trichloroacetic acid/L. J Dairy Res 61 , 365-374

Addeo F, Garro F, Intorcia N, Pellegrino L, Resmini P, Chianese L (1995) Gel electrophoresis for the detection of casein proteolysis in cheese. $J$ Dairy Res 62, 297-309

Adler-Nissen J, (1979) Determination of the degree of hydrolysis of food protein hydrolyzates by trinitrobenzene-sulphonic acid. J Agric Food Chem $27,1256-1262$

Alonso L, Juárez M, Ramos M, Martín-Alvarez PJ (1987) Effects of changes during ripening and frozen storage on the physicochemical and sensory characteristics of Cabrales cheeses. Int J Food Sci Technol 22, 525-534

Amantea GF, Skura BJ, Nakai S (1986) Culture effect on ripening characteristics and rheological behaviour of Cheddar cheese, J Food Sci 51,912-918

Amigo L, Ramos M, Calhau L, Barbosa M (1992) Comparison of electrophoresis, isoelectric focusing, and immunodiffusion in determination of cow's and goat's milk in Serra da Estrela cheeses. Lait 72, 95-101 
Andrews AT (1983) Proteinases in normal bovine milk and their action on caseins. $J$ Dairy Res 50 , 45-55

Anonymous (1989) Ammonia, UV Method for the Determination of Ammonia in Foodstuffs and Other Materials and for the Determination of Nitrogen After Kjeldahl Digestion. BoehringerMannheim, Mannheim, Germany

Ardö Y, Gripon JC (1995) Comparative study of peptidolysis in some semi-hard round-eyed cheese varieties with different fat contents. $J$ Dairy Res $62,543-547$

Ardö Y, Gripon JC (1991) Chromatographic methods used to measure proteolysis in cheese. Bull Int Dairy Fed 261, 29-34

Ardö Y, Meisel H (1991) Methods for direct measurement of peptide bond cleavage in cheese. Bull Int Dairy Fed 261, 10-13

Ashworth US (1966) Determination of protein in dairy products by dye-binding. J Dairy Sci 49, 133-137

Aston JW, Creamer LK (1986) Contribution of the components of the water-soluble fraction to the flavour of Cheddar cheese. NZ J Dairy Sci Technol $21,229-248$

Barlow IE, Lloyd GT, Ramshaw EH (1986) The measurement of proteolysis in Cheddar cheese: a comparison of trinitrobenzene sulphonic acid procedures. Aust J Dairy Technol 41, 79-81

Barrefors P, Ekstrand B, Fagerstam L, LarsonRaznikiewicz M, Scharr J, Steffner P (1985) Fast protein liquid chromatography (FPLC) of bovine caseins. Milchwissenschaft 40, 257-260

Basch JJ, Farrell HM Jr, Walsh RA, Konstance RP, Kumosinski TF (1989) Development of a quantitative model for enzyme-catalyzed, time-dependent changes in protein composition of Cheddar cheese during storage. J Dairy Sci 72, 591-603

Beeby R (1980) Use of fluorescamine at $\mathrm{pH} 6.0$ to follow the action of chymosin on $\kappa$-casein and to estimate this protein in milk. NZ J Dairy $S c i$ Technol 15, 99-108

Bertacco G, Boschella O, Lercker G (1992) Gas chromatographic determination of free amino acids in cheese. Milchwissenschaft 47, 348-350

Bhowmik T, Riesterer R, van Boekel MAJS, Marth EH (1990) Characteristics of low-fat Cheddar cheese made with added Micrococcus or Pediococcus species. Milchwissenschaft 45, 230-235

Bican P, Spahni A (1993) Proteolysis in Swiss-type cheeses; a high performance liquid chromatographic study. Int Dairy J 3, 73-84
Bican P, Blanc B (1982) Milk protein analysis, a high performance chromatography study. Milchwissenschaft 37, 592-593

Bican P, Spahni A (1991) Low molecular mass nitrogen components in ripening cheese. Lebensm Wiss Technol 24, 315-322

Biede SL, Hammond EG (1979) Swiss cheese. I. Chemical analysis. J Dairy Sci 62, 227-237

Blais BW, Cunningham A, Yamazaki H (1994) A novel immunofluorescence capillary electrophoresis assay for the determination of chloramphenicol in milk. Food Agric Immunol 6 , 409-417

Blakesley RW, Boezi JA (1977) A new staining technique for proteins in polyacrylamide gels using Coomassie brilliant blue G250. Anal Biochem 82, 580-582

Bockelmann W (1995) The proteolytic system of starter and non-starter bacteria: components and their importance for cheese ripening. Int Dairy J 5 , 977-994

Bouton Y, Grappin R (1994) Measurement of proteolysis in cheese: relationship between phosphotungstic acid-soluble $\mathrm{N}$ fraction by Kjeldahl and 2, 4, 6-trinitrobenzenesulphonic acid-reactive groups in water-soluble N. J Dairy Res $61,437-440$

Bradford M (1976) A rapid and sensitive method for the quantitation of microgram quantities of protein utilizing the principle of protein-dye binding. Anal Biochem 72, 248-254

Breen ED (1992) Fractionation and identification of water-soluble and water-insoluble cheese nitrogen. MSc thesis, Nat Univ Ireland, Cork

Breen ED, Fox PF, McSweeney PLH (1995) Fractionation of water-soluble peptides from Cheddar cheese. Ital J Food Sci 7, 211-220

Bütikofer U, Fuchs D, Murni D, Bosset JO (1990) Beitrag zur Bestimmung biogener Amine in Käse. Vergleich einer verbesserten HPLC-mit einer ICMethode und Anwendung bei verschiedenen Kasesorten. Mitt Geb Lebensmittelunters Hyg 81, $120-133$

Bütikofer U, Fuchs D, Bosset JO, Gmur W (1991) Automated HPLC-amino acid determination by precolumn derivatization with OPA and FMOC and comparison with classical ion-exchange chromatography. Chromatographia 31, 441-447

Bütikofer U, Ruegg M, Ardo Y (1993) Determination of nitrogen fractions in cheese, evaluation of a collaborative study. Lebensm Wiss Technol 26, 271-275 
Chakravorty SC, Srinivasan RA, Babbar IJ, Dudani AT, Burde SD, Iya KK (1966) Comparative study of proteolysis during ripening of Cheddar cheese by bacterial milk clotting enzymes and rennet extract. Proc 17th Int Dairy Congr, Munich,187-198

Christensen TMIE, Kristiansen KR, Madsen JS (1989) Proteolysis in cheese investigated by high performance liquid chromatography, J Dairy Res 56 , 823-828

Christensen TMIE, Bech A-M, Werner H (1991) Methods for crude fractionation (extraction and precipitation) of nitrogen components in cheese. Bull Int Dairy Fed 261, 4-9

Church FC, Swaisgood HE, Porter DH, Catignani GL (1983) Spectrophotometric assay using $o$-phthaldialdehyde for determination of proteolysis in milk and isolated milk proteins. I Dairy Sci 66 , 1219-1227

Cifuentes A, de Frutos M, Diez-Masa JC (1993) Analysis of whey proteins by capillary electrophoresis using buffer-containing polymeric additives. J Dairy Sci 76, 1870-1875

Citti JE, Sandine WE, Elliker PR (1963) Some observations on the Hull method for measurement of proteolysis in milk. J Dairy Sci 46, 337

Clegg KM, Lee YK, McGilligan JF (1982) Trinitrobenzene sulphonic acid and ninhydrin reagents for the assessment of protein degradation in cheese samples. J Food Technol 17, 517-520

Clemens W (1954) Papierchromatographische Untersuchungen an Käse. Milchwissenschaft 9, 195-201

Cliffe AJ, Law BA (1991) A time course study of peptide production in accelerated-ripened Cheddar cheese using reverse phase high performance liquid chromatography. Food Biotechnol 5, 1-17

Cliffe AJ, Revell D, Law BA (1989) A method for the reverse phase-high performance liquid chromatography of peptides from Cheddar cheese. Food Chem 34, 147-160

Cliffe AJ, Marks JD, Mulholland F (1993) Isolation and characterization of non-volatile flavours from cheese, peptide profile of flavour fractions from Cheddar cheese, determined by reverse phase highperformance liquid chromatography. Int Dairy J 3, 379-387

Conti A, Napolitano L, Cantisani SM, Davoli R, DallOlio S (1988) Bovine beta-lactoglobulin $\mathrm{H}$-isolation by preparative isoelectric-focusing in immobilized $\mathrm{pH}$ gradients and preliminary characterization. J Biochem Biophys Methods 16, 205-214
Creamer LK (1991) Electrophoresis of cheese. Bull Int Dairy Fed 261, 14-28

Creamer LK, Richardson BC (1974) Identification of the primary degradation product of $\alpha_{51}$-casein in Cheddar cheese. NZ I Dairy Sci Technol 9, 9-13

Creamer LK, Olson NF (1982) Rheological evaluation of maturing Cheddar cheese. J Food Sci 41 , 631-636, 646

Creamer LK, Lawrence RC, Gilles J (1985) Effect of acidification of cheese milk on the resultant Cheddar cheese. NZ I Dairy Sci Technol 20,185-203

Davis JG (1965) Cheese. J and A Churchill Ltd, London

de Jong L (1975) A quantitative electrophoretic method of studying cheese ripening. Neth Milk Dairy J 29 , 162-168

de Koning PJ, de Wit JN. Driessen FM (1992) Process conditions affecting age-thickening and gelation of sterilized canned evaporated milk. Neth Milk Dairy J 46, 3-18

Desmazeaud MJ, Gripon JC, Le Bars D, Bergère JL (1976) Etude du role des micro-organismes et des enzymes au cours de la maturation des fromages. III. Influence des micro-organismes. Lait 56 , 379-396

Doi E, Shibata D, Matoba T (1981) Modified colorimetric ninhydrin methods for peptidase assay. Anal Biochem 118, 173-184

Edwards J, Kosikowski FV (1983) Bitter compounds from Cheddar cheese. J Dairy Sci 66, 727-734

El Soda M, Desmazeaud MJ, Aboudonia S, Kamal N (1981) Acceleration of cheese ripening by the addition of whole cells or cell free extracts from Lactobacillus casei to the cheese curd. Milchwissenschaft 36, 140-142

Exterkate FA (1995) Lactococcal cell envelope proteinases: differences, calcium-binding effects and role in cheese ripening. Int Dairy J 5, 995-1018

Fernandez M, Fox PF (1997) Fractionation of cheese nitrogen using chitosan. Food Chem 58, 319-322

Fernandez-Salguero J. Andres Marcos Alcala M, Esteban MA (1989) Proteolysis of Cabrales cheese and other European blue vein cheese varieties. J Dairy Res 56, 141-145

Fields R (1971) The measurement of amino groups in proteins and peptides. Biochem $J 124,581-590$

Folkertsma B, Fox PF (1992) Use of Cd-ninhydrin reagent to assess proteolysis in cheese during ripening, J Dairy Res 59, 217-224

Folkertsma B, Fox PF, McSweeney PLH (1996) Accelerated ripening of Cheddar cheese at elevated temperatures. Int Dairy $J 6,1117-1134$ 
Foster PMD, Green ML (1974) A quantitative gel filtration method for analysis of the proteinaceous fraction of Cheddar cheese. I Dairy Res 41 , 259-268

Fox PF (1989) Proteolysis in cheese during manufacturing and ripening. J Dairy Sci 72, 1379-1400

Fox PF, Singh TK, McSweeney PLH (1995a) Biogenesis of flavour compounds in cheese. In: Chemistry of Structure/Function Relationships in Cheese (Malin EL, Tunick MH, eds) Plenum Publ Corp, New York, 59-98

Fox PF, McSweeney PLH, Singh TK (1995b) Methods for assessing proteolysis in cheese during ripening. In: Chemistry of Structure/Function Relationships in Cheese (Malin EL, Tunick MH, eds) Plenum Publ Corp, New York, 161-194

Friedman M, Pang J, Smith GA (1984) Ninhydrinreactive lysine in food proteins. I Food Sci 49 , $10-13,20$

Furtado MM, Chandan RC (1985) Ripening changes in blue-mold surface ripened cheese from goat's milk. J Food Sci 50, 545-546

Girardet J-M, Saulnier F, Driou A, Linden G, Coddeville G, Spik G (1994) High performance electrophoresis chromatography of bovine milk component 3 glycoproteins. J Dairy Sci 77, 1205-1215

González de Llano D, Ramos M, Polo C (1987) Gel filtration and high performance liquid chromatographic analysis of phosphotungstic acid soluble peptides from blue cheeses. Chromatographia 23 , 764-766

González de Llano D, Polo C, Ramos M (1991) Production, isolation and identification of low molecular mass peptides from blue cheese by high performance liquid chromatography. $J$ Dairy Res 58 , 363-372

González de Llano D, Ramos M, Martín-Alvarez PJ (1993) Comparative study of different methods for evaluating proteolysis in blue cheese. Z Lebensm Unters Forsch 196, 29-31

Gordon MJ, Huang X, Petoney SL Jr, Zare RN (1988) Capillary electrophoresis. Science 242, 224-228

Gouldsworthy AM, Leaver J, Banks JM (1996) Application of mass spectrometry sequencing technique for identifying peptides present in Cheddar cheese. Int Dairy J 6, 781-790

Green ML, Foster PDM (1974) Comparison of the rates of proteolysis during ripening of Cheddar cheeses made with calf rennet and swine pepsin as coagulants. J Dairy Res 41, 269-282

Gripon JC (1993) Mould-ripened cheeses, In: Cheese: Chemistry, Physics and Microbiology, vol 2 (ed, PF
Fox) Chapman and Hall, London, 111-136, 2nd edn

Gripon JC, Desmazeaud MJ, Le Bars D, Bergère JL (1975) Etude du role des micro-organismes et des enzymes au cours de la maturation des fromages. II. Influence de la presure commerciale. Lait 55 , 502-516

Gripon JC, Desmazeaud MJ, Le Bars D, Bergère JL (1977) Role of proteolytic enzymes of Streptococcus lactis, Penicillium roqueforti and Penicillium caseicolum during cheese ripening. J Dairy Sci 60, 1532-1538

Guinee TP, Pudja PD, Reville WJ, Harrington D, Mulholland EO, Cotter M, Cogan TM (1995) Composition, microstructure and maturation of semihard cheeses from high protein ultrafiltered milk retentates with different levels of denatured whey proteins. Int Dairy J 5, 543-568

Guo MR, Kindstedt PS (1995) Age-related changes in the water-phase of Mozzarella cheese. $J$ Dairy Sci 78, 2099-2107

Gupta SK, Whitney RM, Tuckey SL (1974) Brine soluble protein of Cheddar and Gouda cheese. I Dairy Sci 57, 540-544

Haasnoot W, Stouter P, Venema DP (1989) High performance liquid chromatography determination of the extent of proteolysis in Gouda cheese. J Chromatogr 483, 319-329

Habeeb AFS (1966) Determination of free amino groups in proteins by trinitrobenzenesulfonic acid. Anal Biochem 14, 328-336

Harwalkar VR, Elliott JA (1971) Isolation of bitter and astringent fractions from Cheddar cheese. J Dairy Sci 54, 8-11

Hickey MW, van Leeuwen H, Hillier AJ, Jago GR (1983) Amino acid accumulation in Cheddar cheese manufactured from normal and ultrafiltered milk. Aust J Dairy Technol 38, 110-113

Huber L, Klostermeyer H (1974) Isolierung und Identifizierung eines Bitterstoffes aus Butterkäse. Milchwissenschaft 29, 449-455

Hull ME (1947) Studies on milk proteins. II. Colorimetric determination of the partial hydrolysis of the proteins in milk. J Dairy Sci $30,881-884$

Inikhov GS (1951) Chemical Analysis of Milk Products. Part II. Food Industry Publ, Moscow

IDF (1991) Chemical methods for evaluating proteolysis in cheese maturation. Bull Int Dairy Fed 261

Jarrett WD, Aston JW, Dulley JR (1982) A simple method for estimating free amino acids in Cheddar 
cheese. Aust J Dairy Technol 37, 55-58 (corr 1983, 38)

Kaminogawa S, Yan TR, Azuma N, Yamauchi K (1986) Identification of low molecular weight peptides in Gouda-type cheese and evidence for the formation of these peptides from 23-N-terminal residues of $\alpha_{\mathrm{s}_{1}}$-casein by proteinases of Streptococcus cremoris H61. I Food Sci 51, 1253-1256, 1264

Katsiari MC, Voutsinas LP (1994) Manufacture of low-fat Kefalograviera cheese. Int Dairy J 4, 533-553

Kim HH, Jimenez-Flores R (1994) Comparison of milk proteins using preparative isoelectric focusing followed by polyacrylamide gel electrophoresis. J Dairy Sci 77, 2177-2190

Kosikowsky FV (1951a) Paper chromatography of the free amino acids in American Cheddar cheese. J Dairy Sci 34, 228-234

Kosikowsky FV (1951b) The liberation of the free amino acids in raw and pasteurized milk Cheddar cheese during ripening. $J$ Dairy Sci 34, 235-241

Kroger M, Weaver JC (1979) Use of protein dye-binding values as indicators of the 'chemical age' of conventionally made Cheddar cheese and hydrolyzed-lactose Cheddar cheese. J Food Sci 44, 304-305

Kuchroo CN, Fox PF (1982a) Soluble nitrogen in Cheddar cheese: comparison of extraction procedures. Milchwissenschaft 37, 331-335

Kuchroo CN, Fox PF (1982b) Fractionation of watersoluble nitrogen from Cheddar cheese: chemical methods. Milchwissenschaft 37, 651-653

Kuchroo CN, Fox PF (1983a) Fractionation of the water-soluble nitrogen from Cheddar cheese: chromatographic methods. Milchwissenschaft 38 , 76-79

Kuchroo CN, Fox PF (1983b) A fractionation scheme for the water-soluble nitrogen in Cheddar cheese. Milchwissenschaft 38, 389-391

Kuchroo CN, Rahilly J, Fox PF (1983) Assessment of proteolysis in cheese by reaction with trinitrobenzene sulphonic acid. Irish J Food Sci Technol 7, 129-133

Laemmli UK (1970) Cleavage of structural proteins during the assembly of the head of bacteriophage T4. Nature 227, 680-685

Lagerwerf FM, van Wassenaar PD, Haverkamp J (1995) Comparison of Cheddar cheeses produced with recombinant chymosin with calf rennet using two dimensional high-performance liquid chromatography. J Dairy Res 62, 673-679
Laleye LC, Simard RE, Grosselin C, Lee BH, Giroux RN (1987) Assessment of Cheddar cheese quality by chromatographic analysis of free amino acids and biogenic amines. J Food Sci 52 , 303-307, 311

Lane CN, Fox PF (1996) Contribution of starter and adjunct lactobacilli to proteolysis in Cheddar cheese during ripening. Int Dairy J 6, 715-728

Lau KY, Barbano DM, Rasmussen RR (1991) Influence of pasteurization on protein breakdown in Cheddar cheese during aging. J Dairy Sci 74 , 727-740

Lawrence RC, Gilles J, Creamer LK (1983) The relationship between cheese texture and flavour. NZ J Dairy Sci Technol 18, 175-190

Le Bars D, Gripon JC (1989) Specificity of plasmin towards bovine $\alpha_{52}$-casein. J Dairy Res 56 , $817-821$

Ledford RA, O'Sullivan AC, Nath KR (1966) Residual casein fractions in ripened cheese determined by polyacrylamide-gel electrophoresis. J Dairy Sci 49, 1098-1101

Lemieux L, Puchades R, Simard RE (1989) Size-exclusion HPLC separation of bitter and astringent fractions from Cheddar cheese made with added Lactobacillus strains to accelerate ripening. J Food Sci 54, 1234-1237

Lemieux L, Puchades R, Simard RE (1990) Free amino acids in Cheddar cheese: comparison of quantitation methods. J Food Sci 55, 1552-1554

Lindeberg J (1996a) Capillary electrophoresis in food analysis. Food Chem 55, 73-94

Lindeberg J (1996b) Addendum to capillary electrophoresis in food analysis. Food Chem 55, 95-101

Lindqvist B (1962) Preparative separation of high molecular weight peptides of cheese. In: Proc 16th Int Dairy Congr, Copenhagen B, 673-678

Lindqvist B, Storgards T (1959) Changes in casein during cheese ripening. In: Proc 15th Int Dairy Congr, London 2, 679-684

Lindqvist B, Storgards T, Goransson MB (1953) Electrophoresis in paper as a means of studying the ripening process in cheese. Proc 13th Int Dairy Congr, The Hague 3, 1261-1268

Lucey JA, Gorry C, Fox PF (1993) Changes in the acid-base buffering curves during the ripening of Emmental cheese. Milchwissenschaft 48, 183-186

Mabbitt LA (1955) Quantitative estimation of the amino acids in Cheddar cheese and their importance in flavour. $J$ Dairy Res 22, 224-231 
Madkor SA, Fox PF, Shalabi SI, Metwally NH (1987) Studies on the ripening of Stilton cheese: proteolysis. Food Chem 25, 13-19

Marshall T, Gilliland D, Williams KM (1988) Sodium dodecylsulphate/ polyacrylamide gel electrophoresis of milk proteins: application to cheese. Biochem Soc Trans 16, 165-166

Martley FG, Crow VL (1993) Interactions between non-starter microorganisms during cheese manufacture and ripening. Int Dairy $J 3,461-483$

McGann TCA, Mathiassen A, O'Connell JA (1972) Applications of the pro-milk Mk II. III. Rapid estimation of casein in milk and protein in whey. Lab Pract 21, 628-631, 650

McGugan WA, Emmons DB, Larmond E (1979) Influence of volatile and nonvolatile fractions on intensity of Cheddar cheese flavor. $J$ Dairy Sci 62 , 398-403

McSweeney PLH, Fox PF (1993) Cheese, methods of chemical analysis, In: Cheese, Chemistry, Physics and Microbiology. Vol 1. General Aspects (Fox PF, ed) Chapman and Hall, London, 341-388, 2nd edn

MeSweeney PLH, Fox PF, Lucey JA, Jordan KN, Cogan TM (1993a) Contribution of the indigenous microflora to the maturation of Cheddar cheese. Int Dairy J 3, 613-634

McSweeney PLH, Olson NF, Fox PF, Healy A, Hojrup P (1993b) Proteolytic specificity of chymosin on bovine $\alpha_{\mathrm{s} 1}$-casein. J Dairy Res 60, 401-412

McSweeney PLH, Pochet S, Fox PF, Healy A (1994a) Partial identification of peptides from the waterinsoluble fraction of Cheddar cheese. J Dairy Res $61,587-590$

McSweeney PLH, Walsh E, Fox PF, Cogan TM, Drinan FD. Castelo-Gonzalez M (1994b) A procedure for the manufacture of Cheddar cheese under controlled bacteriological conditions and the effect of adjunct lactobacilli on cheese quality. Irish $J$ Agric Food Res 33, 183-192

McSweeney PLH, Lynch CM, Walsh EM, Fox PF, Jordan, KN, Cogan TM, Drinan FD (1995) Role of non-starter lactic acid bacteria in Cheddar cheese ripening. In: Proc 4th Cheese Symp, Moorepark, Fermoy, Co Cork, 32-45

Melachouris NP, Tuckey SL (1966) Changes in the proteins in Cheddar cheese made from milk heated at different temperatures. J Dairy Sci 49, 800-805

Michalke B (1995) Capillary electrophoresis method for a clear identification of Seleno amino acids in complex matrices like human milk. Fresenius $J$ Anal Chem 351, 670-676
Moio L, Di Luccia A, Addeo F (1989) Fast isoelectricfocusing of milk-proteins on small ultrathin polyacrylamide gels containing urea. Electrophoresis $10,533-535$

Moio L, Chianese L, Rivemale M, Addeo F (1992) Fast detection of bovine milk in Roquefort cheese with PhastSystem ${ }^{\circledR}$ by gel isoelectric focusing and immunoblotting. Lait 72, 87-93

Mojarro-Guerra SH, Amado R, Arrigoni E, Solms J (1991) Isolation of low-molecular weight taste peptides from Vacherin Mont d'Or cheese. J Food Sci 56, 943-947

Moore S, Stein WH (1948) Photometric ninhydrin method for use in the chromatography of amino acids. I Biol Chem 176, 367-388

Moore S, Stein WH (1954) A modified ninhydrin reagent for the photometric determination of amino acids and related compounds. J Biol Chem 211, 907-913

Morawski J, Alden P, Sims A (1993) Analysis of cationic nutrients from foods by ion chromatography. I Chromatogr 640, 359-364

Morr CV (1971) Comparison of protein preparation procedures and starch versus polyacrylamide gel electrophoresis for examining casein degradation products in cheese. J Dairy Sci 54, 339-343

Morris HA, Holt C, Brooker BE, Banks JM, Manson W (1988) Inorganic constituents of cheese, analysis of juice from a one-month old Cheddar cheese and the use of light and electron microscopy to characterize the crystalline phases. J Dairy Res 55 , 255-268

Mulvihill DM, Fox PF (1979) Proteolytic specificity of chymosin on bovine $\alpha_{\mathrm{s} 1}$-casein. J Dairy Res $46,641-651$

Nath KR, Ledford RA (1973) Growth response of Lactobacillus casei variety casei to the proteolysis products in cheese during ripening. $J$ Dairy $S c i$ $56,710-715$

Ney KH (1985) N-Endständige Aminosäuren der Peptide aus reifem Cheddarkäse. Milchwissenschaft 40, 207-208

Noomen A (1977a) Noordhollandse Meshanger cheese, a novel method for research on cheese ripening. 2. The ripening of the cheese. Neth Milk Dairy $J 31,75-102$

Noomen A (1977b) A rapid method for the estimation of the dissolved and the undissolved nitrogen compounds in cheese. Neth Milk Dairy J 31 , 163-176 
O'Keeffe AM, Fox PF, Daly C (1978) Proteolysis in Cheddar cheese: role of coagulant and starter bacteria. J Dairy Res 45, 465-477

O'Keeffe RB, Fox PF, Daly C (1976) Contribution of rennet and starter proteases to proteolysis in Cheddar cheese. J Dairy Res 43, 97-107

O'Sullivan M, Fox PF (1990) A scheme for partial fractionation of cheese peptides. J Dairy Res 57 , $135-139$

Ollikainen P (1990) Titration - a rapid method for the determination of proteolysis in cheese. I Dairy Res 57, 149-150

Omar MM (1984) Microstructure, free amino acids and free fatty acids in Ras cheese. Food Chem 15 , 19-29

Ordonez JA, Burgos J (1977) Etude de la variété de fromage «Ulloa». 1. Evolution de la flore microbienne et des composants azotés au cours de la maturation. Lait 57, 150-163

Otte J, Kristiansen KR, Zakora M, Qvist KB (1994) Separation of individual whey proteins and measurement of $\alpha$-lactalbumin and $\beta$-lactoglobulin by capillary zone electrophoresis. Neth Milk Dairy J $48,81-97$

Pant I, Trenerry VC (1995) The determination of sorbic acid and benzoic acid in a variety of beverages and foods by micellar electrokinetic chromatography. Food Chem 53, 219-226

Pearce KN (1979) Use of fluorescamine to determine the rate of release of the caseino-macropeptide in rennet treated milk. NZ J Dairy Sci Technol 14, 233-239

Pearce KN, Karahaliós D, Friedman M (1988) Ninhydrin assay for proteolysis in ripening cheese. J Food Sci 53, 432-435, 438

Peterson RF, Nauman LW, McMeekin TL (1957) The separation of amino acid composition of a pure phosphopeptone prepared from $\beta$-casein by the action of trypsin. J Am Chem Soc 80, 95-99

Peterson SD, Marshall RT (1990) Nonstarter lactobacilli in Cheddar cheese: a review. I Dairy Sci $73,1395-1410$

Petrilli P (1982) A simple BASIC program for peptide localization by its amino acid composition. Ital J Biochem 31, 391-395

Pham AM, Nakai S (1984) Application of stepwise discriminant analysis to high-pressure liquid chromatography profiles of water extract for judging ripening of Cheddar cheese. J Dairy Sci 67 , 1390-1396

Picon A, Gaya P, Medina M, Nuñez M (1994) The effect of liposome encapsulation of chymosin derived by fermentation on Manchego cheese ripening, $J$ Dairy Sci 77, 16-23

Polo C, Ramos M, Sanches R (1985) Free amino acids by high performance liquid chromatography and peptides by gel electrophoresis in Mahon cheese during ripening. Food Chem 16, 85-96

Polychroniadou A (1988) A simple procedure using trinitrobenzene sulphonic acid for monitoring proteolysis in cheese. J Dairy Res $55,585-596$

Polychroniadou A, Vlachos J (1979) Les acides aminés du fromage Télémé. Lait 59, 234-243

Poznanski S, Habaj B, Rymaszewski J, Rapazynski $T$ (1966) Influence of different starter cultures on the protein breakdown in Edam cheese. In: Proc 17th Int Dairy Congr, Munich, 555-564

Pretswell EL, McGaw BA, Morrison AR (1995) The comparison of capillary zone electrophoresis and atomic spectroscopy for the determination of the cation content of a standard reference material IAEA-A-11 milk powder. Talanta 42, 283-289

Puchades R, Lemieux L, Simard RE (1989a) Evolution of free amino acids during the ripening of Cheddar cheese containing added lactobacilli strains. J Food Sci 54, 885-888, 946

Puchades R, Lemieux L, Simard RE (1989b) Sensitive, rapid and precise determination of L-glutamic acid in cheese using a flow injection system with immobilized enzyme column. J Food Sci 54, 423-426

Puchades R, Lemieux L, Simard RE (1990) Determination of free amino acids in cheese by flow injection analysis with an enzyme reactor and chemiluminescence detector. J Food Sci 55, 1555-1558. 1578

Ramos M, Caceres 1, Polo C. Alonso L, Juarez M (1987) Effect of freezing on soluble nitrogen fraction of Cabrales cheese. Food Chem 24, 271-278

Rank TC, Grappin R, Olson NF (1985) Secondary proteolysis of cheese during ripening. A review. J Dairy Sci 68, 801-805

Reiter B, Sorokin Y, Pickering A, Hall AJ (1969) Hydrolysis of fat and protein in small cheeses made under aseptic conditions. I Dairy Res 36, 65-76

Reps A (1993) Bacterial surface-ripened cheeses. In: Cheese, Chemistry, Physics and Microbiology, vol 2 (Fox PF, ed) Chapman and Hall, London, $137-172,2$ nd edn

Reville WJ, Fox PF (1978) Soluble protein in Cheddar cheese. A comparison of analytical methods. Irish J Food Sci Technol 2, 67-76

Roudot-Algaron F, Le Bars D, Einhorn J, Adda J, Gripon JC (1993) Flavor constituents of aqueous 
fraction extracted from Comté cheese by liquid carbon dioxide. I Food Sci 58, 1005-1009

Roudot-Algaron F, Kerhoas L, Le Bars D, Einhorn J, Gripon JC (1994) Isolation of $\gamma$-glutamyl peptides from Comté cheese. J Dairy Sci 77, 1161-1166

Salji JP, Kroger M (1981) Proteolysis and lipolysis in ripening Cheddar cheese made with conventional bulk starter and with frozen concentrated direct-to-the-vat culture. I Food Sci 46, 1345-1348

Salvat-Brunaud D, Maubois JL, Le Graet Y, Piot M, Maillard MB, Corre C. Thierry A (1995) Extraction et analyse de la phase aqueuse de I'Emmental à quatre stades d'affinage. Lait 75, 239-249.

Samples DR, Richter RL, Dill CW (1984) Measuring proteolysis in Cheddar cheese slurries, comparison of Hull and trinitrobenzene sulfonic acid procedures. J Dairy Sci 67, 60-63

Santoro M, Leone AM, La Notte E, Liuzzi VA (1987) Fractionation of soluble nitrogen in Provolone cheese. I. Milchwissenschaft 42, 709-712

Schmitt M, Saulnier F, Malhautier L, Linden G (1993) Effect of temperature on the salt balance of milk studied by capillary electrophoresis. I Chromatogr $640,419-424$

Sciancalepore V, Alviti FS (1987) A dialysis method for measuring cheese ripening. Milchwissenschaft $42,220-221$

Sciancalepore V, Longone V (1988) Rapid methods for measuring the degree of proteolysis as cheese ripening index. Milchwissenschaft 43, 357-359

Shalabi SI, Fox PF (1987) Electrophoretic analysis of cheese: comparison of methods. Irish J Food Sci Technol 11, 135-151

Shindo K, Sakurada K, Niki R, Arima S (1980) Studies on immobilized chymosin. 5. Experiments in cheese-making with immobilized chymosin. Milchwissenschaft 35, 527-530

Singh A, Ganguli NC (1972) Changes in peptides and amino acids in cheese during ripening. Milchwissenschaft 27, 412-416

Singh TK, Fox PF, Højrup P, Healy A (1994) A scheme for the fractionation of cheese nitrogen and identification of principal peptides, Int Dairy J 4, 111-122

Singh TK, Fox PF, Healy A (1995) Water soluble peptides in Cheddar cheese: isolation and identification of peptides in the UF retentate of water-soluble fractions. J Dairy Res 62, 629-640

Singh TK, Fox PF, Healy A (1997) Isolation and identification of further peptides in the diafiltration retentate of the water-soluble fraction of Cheddar cheese. J Dairy Res 64 (in press)
Smith AM, Nakai S (1990) Classification of cheese varieties by multivariate analysis of HPLC profiles. Can Inst Food Sci Technol J 23, 53-58

St. Martin M, Paquin P (1990) Ion exchange fast protein liquid chromatography, optimization of the purification of caseins using a non-denaturing detergent. J Dairy Res 57, 63-68

Storgards T, Lindqvist B (1953) Untersuchungen über die Käsereifung. I. Chromatographische Untersuchungen über das Vorkommen von Aminosäuren in verschiedenen Käsesorten. Milchwissenschaft 8, $5-10$

Strange ED, Malin EL, Van Hekken DL, Basch JJ (1992) Chromatographic and electrophoretic methods used for analysis of milk proteins. J Chromatogr 624, 81-102

Tegtmeyer P, Schwartz M, Collins JK, Rundell K (1975) Regulation of tumor antigen synthesis by simian virus 40 gene A. J Virol 16, 168-178

Tieleman AE, Warthesen JJ (1991) Comparison of three extraction procedures to characterize Cheddar cheese proteolysis. J Dairy Sci 74, 3686-3694

Tienstra PA, van Reil JAM, Mingorance MD, Olieman C (1992) Assessment of the capabilities of capillary zone electrophoresis for the determination of hippuric and orotic acid in whey. $J$ Chromatogr 608, $357-361$

Tokita F, Nakanishi T (1962) On the distributive patterns of lower molecular weight peptides in cheese. Milchwissen.schaft 17, 198-201

Tokita F, Hosono A (1968) An investigation about Limburger cheese ripening by gel filtration on Sephadex. Milchwissenschaft 23, 758-761

Trieu-Cuot P, Gripon JC (1982) A study of proteolysis during Camembert cheese ripening using isoelectric focusing and two-dimensional electrophoresis. I Dairy Res 49, 501-510

Tsarichenko AP (1966) New ninhydrin reagent for quantitative determination of amino acids in eluates in column chromatography. Nauchn Tr Krasnodar Gos Pedogog Inst 70, 86-88; cited from Chem Abstr (1967) 67,79479c

Tunick MH, Mackey KL, Shieh JJ, Smith PW, Cooke P, Malin EL (1993) Rheology and microstructure of low-fat Mozzarella cheese, Int Dairy J 3 , 649-662

Udenfried S, Stein S, Bohlen P, Darman W Leimgruber W, Weigele M (1972) Fluorescamine, a reagent for assay of amino acids, peptides, proteins and primary amines in the picomole range. Science $178,871-872$ 
Urbach G (1993) Relations between cheese flavour and chemical composition. Int Dairy J3, 389-422

Vakaleris DG, Price WV (1959) A rapid spectrophotometric method for measuring cheese ripening. J Dairy Sci 42, 264-276

Vakaleris DG, Olson NF, Price WV, Knight SG (1960) A study of the ripening of Dariworld and Cheddar cheese with special emphasis on proteolysis. J Dairy Sci 43, 1058-1067

van den Berg G, de Koning PJ (1990) Gouda cheesemaking with purified calf chymosin and microbiologically produced chymosin. Neth Milk Dairy J $44,189-205$

van Hekken DL, Thompson MP (1992) Application of Phast ${ }^{\mathrm{TM}}$ system to the resolution of bovine milk proteins on urea-polyacrylamide gel electrophoresis. J Dairy Sci 75, 1204-1210

van Hooydonk ACM, Olieman C (1982) A rapid sensitive high-performance liquid chromatographic method of following the action of chymosin in milk. Neth Milk Dairy J 36, 153-158

Venema DP, Herstel H, Elenbaas HL (1987) Determination of ripening time of Edam and Gouda cheese by chemical analysis. Neth Milk Dairy $J$ 41, 215-226

Vijayalakshmi MA, Lemieux L, Amiot J (1986) High performance size exclusion liquid chromatography of small molecular weight peptides from protein hydrolysates using methanol as mobile phase additive. I Liq Chromatogr 9, 3559-3576

Visser FMW (1977) Contribution of enzymes from rennet, starter bacteria and milk to proteolysis and flavour development in Gouda cheese. 3. Protein breakdown, analysis of the soluble nitrogen and amino acid fractions. Neth Milk Dairy J 31 , 210-239

Visser S, Slangen KJ, Hup G (1975) Some bitter peptides from rennet-treated casein. A method for their purification, utilizing chromatographic separation on silica gel. Neth Milk Dairy J 29, 319-334

Visser S, Hup G, Exterkate FA, Stadhouders J (1983a) Bitter peptides in cheese. 2. Model studies on the formation and degradation of bitter peptides by proteolytic enzymes from calf rennet, starter cells and starter cell fractions. Neth Milk Dairy J 37, 169-180

Visser S, Slangen KJ, Hup G, Stadhouders J (1983b) Bitter flavour in cheese. 3. Comparative gel-chromatographic analysis of hydrophobic peptide fractions from twelve Gouda-type cheeses and identification of bitter peptides isolated from a cheese made with Streptococcus cremoris strain HP. Neth Milk Dairy J 37, 181-192
Vreeman MJ, van Riel JAM (1990) The large-scale isolation of $\alpha_{\mathrm{s}_{2}}$-casein from bovine casein. Neth Milk Dairy J 44, 43-48

Vreeman WJ, Visser S, Slangen CJ, van Riel JAM (1986) Characterization of bovine $\kappa$-casein fractions and the kinetics of chymosin-induced macropeptide release from carbohydrate-free and carbohydrate-containing fractions determined by high performance gel permeation chromatography. Biochem J 240, 87-97

Wallace JM, Fox PF (1994) Comparison of different methods for quantitation of peptides/amino acids in the water-soluble fraction of Cheddar cheese. In: Proc FLAIR Meeting, Lisbon, 15-18 April 1994, 41-58

Weaver JC, Kroger M, Thompson MP (1978) Free amino acid and rheological measurement on hydrolysed lactose Cheddar cheese during ripening. J Food Sci 43, 579-583

Weigele M, de Bernardo SL. Tengi JP, Leimgruber W (1972) A novel reagent for the fluorometric assay of primary amines. I Am Chem Soc 94, 5927-5928

Wilkinson MG, Guinee TP, O'Callaghan DM, Fox PF (1992) Effect of commercial enzymes on proteolysis and ripening in Cheddar cheese. Lait 72 , 449-459

Wilkinson MG, Guinee TP, O'Callaghan DM, Fox PF (1994) Autolysis and proteolysis in different strains of starter bacteria during Cheddar cheese ripening. I Dairy Res 61, 249-262

Wood AF, Aston JW, Douglas GK (1985) The determination of free amino acids in cheese by capillary column gas-liquid ehromatography. Aust J Dairy Technol 40, 166-169

Young PM, Astephen NE, Wheat TE (1992) Effects of $\mathrm{pH}$ and buffer composition on peptide separations by high-performance liquid chromatography and capillary electrophoresis. LC-GC 10, 26-30

Yun JJ, Barbano DM, Kindstedt PS, Larose KL (1995) Mozzarella cheese: impact of whey $\mathrm{pH}$ at draining on chemical composition, proteolysis, and functional properties. I Dairy Sci 78, 1-7

Yvon M, Chabanet C, Pélissier JP (1989) Solubility of peptides in trichloroacetic acid (TCA) solutions. Int J Peptide Protein Res 34, 166-176

Zarmpoutis IV, McSweeney PLH, Beechinor J, Fox PF (1996) Proteolysis in the Irish farmhouse blue cheese, Chetwynd. Irish J Agric Food Res 35, 25-36

Zeece M (1992) Capillary electrophoresis: a new analytical tool for food science. Trends Food Sci Technol 3, 6-10 